\title{
Mercury in the snow and firn at Summit Station, Central Greenland, and implications for the study of past atmospheric mercury levels
}

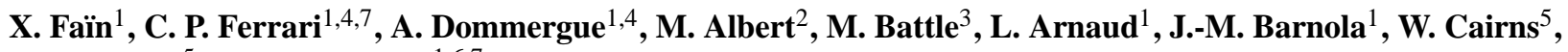 \\ C. Barbante ${ }^{5}$, and C. Boutron ${ }^{1,6,7}$ \\ ${ }^{1}$ Laboratoire de Glaciologie et Géophysique de l'Environnement (UMR 5183 CNRS/Université Joseph Fourier), 54 rue \\ Molière, B.P. 96, 38402 St Martin d'Heres cedex, France \\ ${ }^{2}$ Geophysical Sciences Division - ERDC Cold Regions Research \& Engineering Lab, 72 Lyme Road, Hanover, N.H. 03755, \\ USA \\ ${ }^{3}$ Dept. of Physics and Astronomy - Bowdoin College, 8800 College Station, Brunswick, ME 04011-8488, USA \\ ${ }^{4}$ Polytech' Grenoble, Université Joseph Fourier, 28 avenue Benoît Frachon, B.P. 53, 38041 Grenoble cedex, France \\ ${ }^{5}$ Environmental Sciences Department, University of Venice, Calle Larga S. Marta, 2137, 30123 Venice, Italy \\ ${ }^{6}$ Unité de Formation et de Recherche de Physique, Université Joseph Fourier, B.P. 53, 38041 Grenoble cedex, France \\ ${ }^{7}$ Institut Universitaire de France, 103 boulevard Saint-Michel, 75005 Paris, France
}

Received: 18 September 2007 - Published in Atmos. Chem. Phys. Discuss.: 19 December 2007

Revised: 18 April 2008 - Accepted: 2 June 2008 - Published: 2 July 2008

\begin{abstract}
Gaseous Elemental Mercury ( $\mathrm{Hg}^{\circ}$ or GEM) was investigated at Summit Station, Greenland, in the interstitial air extracted from the perennial snowpack (firn) at depths ranging from the surface to $30 \mathrm{~m}$, during summer 2005 and spring 2006. Photolytic production and destruction of $\mathrm{Hg}^{\circ}$ were observed close to the snow surface during summer 2005 and spring 2006, and we observed dark oxidation of GEM up to $270 \mathrm{~cm}$ depth in June 2006. Photochemical transformation of gaseous elemental mercury resulted in diel variations in the concentrations of this gas in the near-surface interstitial air, but destruction of $\mathrm{Hg}^{\circ}$ was predominant in June, and production was the main process in July. This seasonal evolution of the chemical mechanisms involving gaseous elemental mercury produces a signal that propagates downward through the firn air, but is unobservably small below $15 \mathrm{~m}$ in depth. As a consequence, multi-annual averaged records of GEM concentration should be well preserved in deep firn air at depths below $15 \mathrm{~m}$, and available for the reconstruction of the past atmospheric history of GEM over the last decades.
\end{abstract}

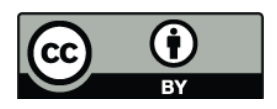

Correspondence to: X. Faï (fain@lgge.obs.ujf-grenoble.fr)

\section{Introduction}

Mercury is a persistent and toxic heavy metal present in the environment in various chemical forms. In the atmosphere, gaseous elemental mercury $\left(\mathrm{Hg}^{\circ}, \mathrm{GEM}\right)$ is the predominant form of mercury $(>95 \%)$ and has a global atmospheric residence time of about 6-24 months (Lamborg et al., 2002). The relatively inert GEM can undergo long-range transport whereas oxidized species of mercury such as particulate mercury (PM) and reactive gaseous mercury (RGM) are subject to rapid deposition near their emission sources. Atmospheric mercury depletion events (AMDEs) were first observed at Alert, Canada (Schroeder et al., 1998). They commonly occur during the spring in polar environments and are characterized by rapidly decreasing concentrations of GEM in the atmosphere. The decrease is caused by photochemically initiated oxidation reactions involving marine halogens ( $\mathrm{Lu}$ et al., 2001; Lindberg et al., 2002; Skov et al., 2004) that transform GEM to RGM and PM. These oxidized species can be deposited onto snow surfaces. As a result, the arctic seasonal snowpack is suspected to contribute to the contamination of the aquatic reservoir during snowmelt. Conversely, the polar snowpack can also act as a source of GEM to the atmosphere. Direct photoreduction of divalent mercury (Hg(II)) complexes deposited onto snow surfaces lead to an emission of GEM to the atmosphere. AMDEs have only been observed in coastal areas. Brooks et al. (2007) reported preliminary observations about mercury chemistry at the South Pole, but

Published by Copernicus Publications on behalf of the European Geosciences Union. 
there is still a clear lack of data on inland Greenland and Antarctica, even though these ice sheets represent a surface of $\sim 14$ millions $\mathrm{km}^{2}$ of snow which could strongly interact with the lower atmosphere and influence the global cycle of mercury.

Atmospheric mercury pollution over the last 150 years has greatly increased mercury deposition to terrestrial and aquatic ecosystems in remote areas. Modern measurements combined with historical records from lake sediments and peat suggest a threefold increase in mercury deposition since pre-industrial times (Engstrom and Swain, 1997; Lamborg et al., 2002). A single ice core profile from the Freemont Glacier (Wyoming, USA) showed a 20-fold increase since 1840 (Schuster et al., 2002) for $\mathrm{Hg}$ (II) deposition. Mason et al. (1994) and Mason and Sheu (2002) used archives of deposited mercury and modeling studies to estimate an increase in the global atmospheric reservoir's GEM concentrations by a factor of 2-5 since the beginning of the industrialized period. Only total and reactive mercury can be investigated in sediment, peat and ice archives, however, postdeposition processes may strongly modify the chemical information trapped into these records (see e.g. Biester et al., 2007). Consequently, these archives do not provide direct information on the evolution of the global background concentration of atmospheric GEM over time.

The potential of the polar ice sheets to serve as an archive for the reconstruction of past atmospheric GEM composition has been well recognized. From the top surface to $\sim 60$ $120 \mathrm{~m}$ depth is the firn, an openly porous and permeable media through which air can diffuse. The solid ice is located below the firn, and the transition between firn and ice is called the close-off. Ice core records of trapped gases and interstitial firn air have been used extensively to study the past history of atmospheric greenhouse gases (Schwander et al., 1988; Siegenthaler et al., 2005). In principle, both firn air and ice cores should also be useful for quantifying the histories of atmospheric GEM concentrations.

However, to correctly interpret GEM measurements from the deep firn air or in the ice air, we first need to quantify any perturbations in the GEM records arising from surface phenomena. For example, chemical processes leading to production and/or destruction of GEM close to the snow-air interface might distort atmospheric properties preserved in the glacial records. More generally, physical and chemical modifications of GEM signals in the lower atmosphere, the surface snowpack and the deep firn have to be understood to determine the transfer function. The GEM transfer function is defined as the relation between GEM atmospheric concentrations and GEM concentrations in deep ice bubbles. This function has to be determined in order to reconstruct the past history of GEM in the atmosphere.

We measured, for the first time, GEM concentrations from the top surface to a depth of $30 \mathrm{~m}$ at Summit Station, Central Greenland, during two field campaigns during summer 2005 and spring 2006. The aims of this study were (i) to docu- ment the chemical processes involving GEM in the shallow firn air and (ii) to understand the influence of these surface processes on the GEM levels in the deep firn air. We also discuss the feasibility of using the GEM transfer function to reconstruct past atmospheric GEM levels from deep firn air and air trapped in ice.

\section{Experimental}

\subsection{Study site}

GEM was investigated on the Greenland ice sheet at the Greenland Environmental Observatory $\left(72.6^{\circ} \mathrm{N}, 38.5^{\circ} \mathrm{W}\right.$, $3200 \mathrm{~m}$ elevation) from 23 to 29 July 2005 (summer 2005) and 29 May to 6 June 2006 (spring 2006). In 2005, atmospheric and snow air samplings were carried out close to the Science Trench: a clean area where access was restricted. In 2006, atmospheric air, snow air and firn air were sampled in a remote location $10 \mathrm{~km}$ away from the station. These measurements were part of the collaborative firn air sampling campaign "Firn structure, interstitial processes, and the composition of firn air at Summit, Greenland" led by CREEL, Hanover, N.H. (USA).

\subsection{In situ air analysis}

We measured GEM levels with two Tekran gas phase GEM analyzers (Model 2537A; Tekran Inc., Toronto, Canada). One was dedicated to ambient and shallow firn measurements, while the other was used exclusively for deeper firn measurements. A precision mass flow meter supplies the 2537A with a sample volume referenced to NTP (Normal Temperature and Pressure: $\left.20^{\circ} \mathrm{C}, 1 \mathrm{~atm}\right)$. The pre-filtered air stream (soda lime trap and $0.2 \mu \mathrm{m}$ Teflon particle filter) is collected on two gold cartridges. GEM is thermally desorbed from the cartridges and detected by cold vapor atomic fluorescence spectrometry (AFS) at $253.7 \mathrm{~nm}$ (Tekran, 1999). Dual gold cartridges allow alternate sampling and desorption, resulting in continuous measurement of GEM on a predefined time base. The set-up, accuracy and precision of this instrument have been assessed during field intercomparisons at an urban/industrial site (Schroeder et al., 1995) and at a remote marine background location (Ebinghaus et al., 1999). The Tekran analyzer was operated with a 5-min sampling frequency and the air was sampled at a flow rate of $11 \mathrm{~min}^{-1}$. The analyzer was calibrated every $25 \mathrm{~h}$ with an internal automatic permeation source injection. The detection limit for GEM in this operational mode is roughly $0.15 \mathrm{ng} \mathrm{m}^{-3}$ (Aspmo et al., 2005). All GEM data discussed in this paper are presented with one StDv.

We measured GEM concentrations between depths of 40 and $330 \mathrm{~cm}$ below the snow surface using GAMAS probes (Gaseous Mercury in Interstitial Air in Snow), devices dedicated to the sampling of GEM and temperature measurements in the air of snowpacks (Dommergue et al., 2003a). 
This system has been used successfully in different Arctic sites, for example, at Station Nord, Greenland (Ferrari et al., 2004a, b), Kuujjuarapik, Canada (Dommergue et al., 2003b) and Col de Porte, French Alps (Faïn et al., 2007). Ten GAMAS probes and an atmospheric sampling line were connected to the Tekran analyzer using an 11-port Teflon solenoid switch. This set-up allowed a cyclic sampling of each probe every $10 \mathrm{~min}$.

\subsection{Firn air sampling}

Firn air was sampled using established methods (Schwander et al., 1988; Battle et al., 1996; Butler et al., 1999) from one hole at the depths of $15,25,30,40,50,58,63,66$, $70,72,74,76,78$ and $79.5 \mathrm{~m}$, but only the top three depths will be discussed in this manuscript. Briefly, a 5-m long bladder was lowered into the borehole after drilling to the sampling depth, and was pressurized, effectively sealing the borehole. Two Dekabon ${ }^{\circledR}$ (polyethylene/aluminum composite) lines were used to pump firn air from a space left immediately below the bladder. These lines drew air from two separate openings separated by a horizontal stainless steel baffle nearly as wide as the hole. Air was pumped from the upper opening at $\sim 201 \mathrm{~min}^{-1}$ and was directed to waste after measuring the $\mathrm{CO}_{2}$ concentration (in situ measurements using a LICOR instrument). When $\mathrm{CO}_{2}$ levels stabilized, indicating effective removal of contamination by younger and/or ambient air, sampling started from the lower opening. Pumping from the upper opening continued during sampling to remove any air leaking from within or around the bladder. It also served to keep sampled air out of contact with the bladder itself. Firn air was collected in pressurized flasks for analysis of other gas species at a flow of $41 \mathrm{~min}^{-1}$ during approximately one hour. Afterwards, the sampling line was connected to a Vacuubrand PTFE pump (MZ-2C) and GEM analyses commenced. The pump delivered firn air to the inlet of a 2537A Tekran analyzer at a flow rate of $11 \mathrm{~min}^{-1}$. Blanks of the Dekabon ${ }^{\circledR}$ sampling line were checked both at the beginning and at the end of the field work. They were $0.08 \pm 0.13 \mathrm{ng} \mathrm{m}^{-3}$ ( $n=8$, before sampling, on 25 May) and $0.01 \pm 0.06 \mathrm{ng} \mathrm{m}^{-3}$ ( $n=18$, after sampling, on 1 June). We measured blanks of the PTFE pump before and after sampling at all depths to quantify any contamination introduced by this additional pump.

\subsection{Pressure influence on GEM analysis}

Summit Station elevation is $3200 \mathrm{~m}$, and an atmospheric pressure of $\sim 675$ mbar was observed both during July 2005 and June 2006. While our 2537A analyzers are optimized for GEM determination in the air from the sea-level atmosphere up to $2000 \mathrm{~m}$ (Tekran Inc., Toronto, Canada), Ebinghaus and Slemr (2000) have shown that low pressures can influence the operation of these analyzers. Using ground calibrations, these authors reported a pressure dependency of the AFS detector of about $0.1 \% \mathrm{mbar}^{-1}$ over the tested range of pressures (980 to 620 mbar). Unfortunately, we could not use such results because we calibrated both Tekran analyzers automatically using an internal calibration source every $25 \mathrm{hrs}$ at Summit Station. Instead, we carried out laboratory studies to obtain information about the effect of low pressure on internal calibrations. While both analyzers were at ambient pressure ( $\sim 990 \mathrm{mbar}$ ), all the inlet and outlets (including internal calibration inlets) were introduced into a lowpressure chamber. This equipment, located at the Centre de Recherche du Service de Santé des Armées (CRSSA, La Tronche, France) and initially designed for biological studies, had a volume of 20001 and could reach a stable pressure from ambient to 500 mbar in a few minutes. The accuracy of the pressure measurement in the chamber was \pm 6 mbar. We first did internal calibrations at $675 \mathrm{mbar}$ to reproduce the conditions of Summit Station. Then, we performed 14 manual injections $\left(\sim 120 \mathrm{pg}\right.$ of $\left.\mathrm{Hg}^{\circ}\right)$ using a primary mercury vapor source (Tekran 2505), using the manual injection port. Because the instruments were at a higher pressure than their internal plumbing, we also sampled mercury free air to check that no invasion of ambient air occurred. The response of both instruments was found to be pressure dependent: at 675 mbar we observed an increase of the GEM signal by 6.2 and $9.4 \%$ for the two analyzers (serial numbers 209 and 238, respectively). All data discussed in this study were pressure corrected.

\subsection{Snow sampling}

A 2-m snowpit was dug in the clean air sector of Summit Station, $500 \mathrm{~m}$ south of the Science Tower. The pit was sampled for total mercury $\left(\mathrm{Hg}_{T}\right)$ on 23 July 2005, in a location where the snow had not been previously disturbed. All samples were immediately stored in the dark at $-20^{\circ} \mathrm{C}$ until analysis. For $\mathrm{Hg}_{\mathrm{T}}$ samples, we used ultra clean Teflon bottles and clean snow sampling procedures (Ferrari et al., 2000). $\mathrm{Hg}_{\mathrm{T}}$ includes species such as $\mathrm{HgCl}_{2}, \mathrm{Hg}(\mathrm{OH})_{2}, \mathrm{HgC}_{2} \mathrm{O}_{4}$ that are easily reducible by $\mathrm{SnCl}_{2}$ or $\mathrm{NaBH}_{4}$, as well as stable complexes such as $\mathrm{HgS}$ and $\mathrm{Hg}^{2+}$ bound to sulfur in humic compounds, and some organomercuric species (Lindqvist and Rodhe, 1985). $\mathrm{Hg}_{\mathrm{T}}$ was determined at the Department of Environmental Science of the University Ca'Foscari of Venice (Italy), using an Element ICP-SFMS (Thermo Finnigan MAT Instrument, Bremen, Germany). Planchon et al. (2004) gave a detailed description of the analytical technique. Instrumental calibrations were carried out with $\mathrm{Hg}$ standards prepared from serial dilutions of a monoelemental $\mathrm{Hg}^{2+}$ solution at $1000 \mathrm{mg}^{-1}$ (CPI International Santa Rosa, CA, USA). Using these techniques, the laboratory achieved a lower detection limit of $\sim 0.18 \mathrm{ng}^{-1}$. The precision of the measurements was estimated to be $15 \%$ (the relative standard deviation of five replicates). Snow samples were melted just prior to analysis to minimize mercury transformation during storage. 


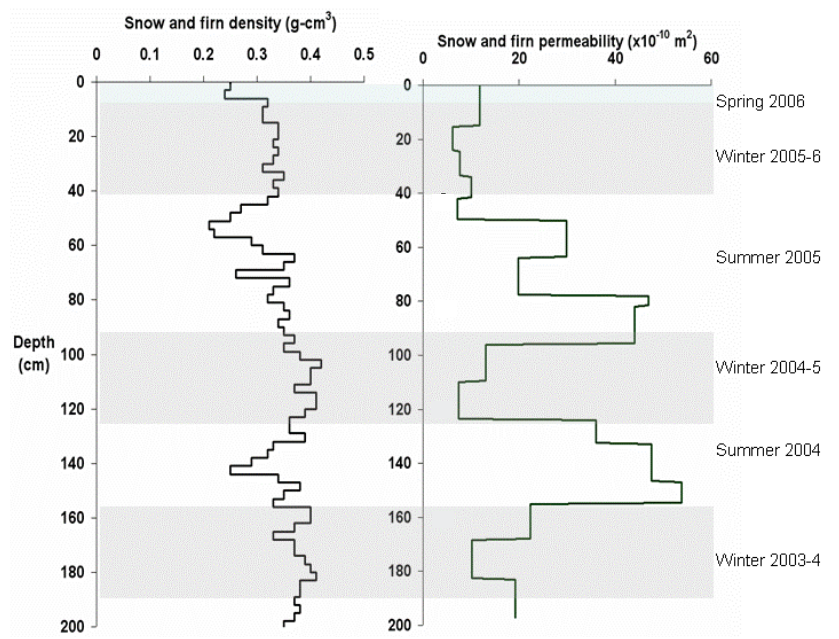

Fig. 1. Measured density and permeability profiles in the snow and firn in early June, 2006, at the firn air sampling site at Summit, Greenland.

\section{Results and discussion}

\subsection{Meteorological conditions}

During both field measurement campaigns, there was 24-h daylight. During summer 2005, atmospheric temperatures and wind speeds exhibited two different periods. From 18 to 25 July wind speeds were always below $3 \mathrm{~m} \mathrm{~s}^{-1}$ while from 26 and 27 July wind speed was typically between 3 and $5 \mathrm{~m} \mathrm{~s}^{-1}$. From 18 to 22 July atmospheric temperatures ranged from $-20^{\circ} \mathrm{C}$ at night to $-5^{\circ} \mathrm{C}$ during the day. From 24 to 27 July 2005, air temperatures during the days were close to $0^{\circ} \mathrm{C}$. During spring 2006 , the daily temperature ranged between $-30^{\circ} \mathrm{C}$ at night and $-15^{\circ} \mathrm{C}$ during the day. Weather conditions were generally calm and clear with a maximum wind speed of $4 \mathrm{~m} \mathrm{~s}^{-1}$ (measured two meters above the snow surface). The only exception was on 6 June when a maximum wind speed of $6 \mathrm{~m} \mathrm{~s}^{-1}$ was recorded. The hemispherical integrated incoming radiation measured at a height of two meters during both field campaigns are shown, along with the shallow firn air data, in Figs. 3 and 4.

\subsection{Snow and firn characteristics}

The physical properties of the Summit snowpack have been intensively studied before. We measured density in 2-m pits both in summer 2005 and spring 2006, finding a pattern similar to that of Albert and Shultz (2002). Our 2-m pit represented about three years of snow accumulation. In May and early June, most of the top $50 \mathrm{~cm}$ of snow is fine-grained wind-packed snow. Low-density hoar layers form occasionally during summer. In accumulated firn from previous years, the layers of hoar from the summer alternate visibly with high density wind-pack layers characteristic of winters. The

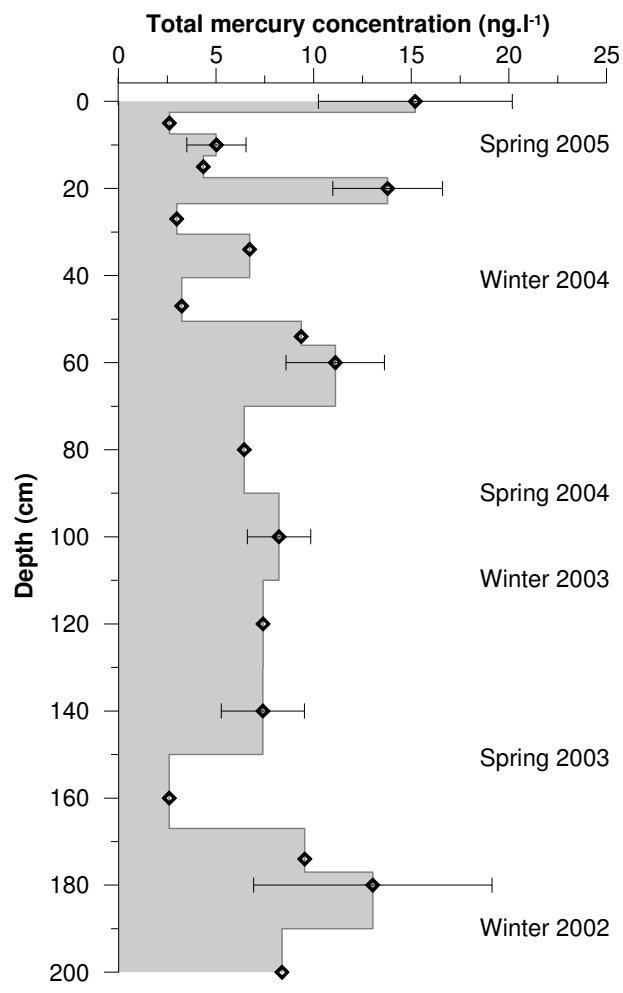

Fig. 2. Total mercury concentrations in the snowpack from the surface to $200 \mathrm{~cm}$ depth, sampled on 23 July 2005 . Seven duplicates collected and analyzed are represented.

density and permeability measurements from the top two meters of firn from the early June 2006 snow pit are shown on Fig. 1. In spring 2006, the snowpack exhibited thick layers of hoar centered at approximately $\sim 55$ and $\sim 140 \mathrm{~cm}$ depths, with large grains and low snow density of about $0.2 \mathrm{~g} \mathrm{~cm}^{-3}$. In summer 2005, similar hoar layers were observed centered at $\sim 80$ and $\sim 150 \mathrm{~cm}$ depths. At Summit, the permeability generally increases with depth by more than an order of magnitude in the first $3 \mathrm{~m}$ of the snowpack (Albert and Shultz, 2002), and generally decreases below $3 \mathrm{~m}$.

To assess the role of total mercury in chemical processes, we sampled the full $2 \mathrm{~m}$ of our pit for $\mathrm{Ca}^{2+}$ and $\mathrm{Na}^{+}$abundance, as well as for $\mathrm{Hg}_{\mathrm{T}}$ in summer 2005. We used $\mathrm{Ca}^{2+}$ and $\mathrm{Na}^{+}$measurements (not shown here) for pit dating. $\mathrm{Ca}^{2+}$ concentration peaks at $\sim 10, \sim 90$ and $\sim 150 \mathrm{~cm}$ depths indicating spring layers, while $\mathrm{Na}^{+}$concentration peaks at $\sim 40$, $\sim 110$ and $\sim 170 \mathrm{~cm}$ depths showing winter layers were observed. $\mathrm{Hg}_{\mathrm{T}}$ concentrations shown in Fig. 2 ranged from 2.6 to $20.2 \mathrm{ng} \mathrm{l}^{-1}$, with a mean value of $10.3 \mathrm{ng}^{-1}$ and a mean analytical uncertainty of $0.7 \mathrm{ng} \mathrm{l}^{-1}$. We collected duplicate samples at the snow surface and at 10,20,60,100,140, and $180 \mathrm{~cm}$ depths, the concentrations reported at these depths on Fig. 2 are the means of duplicate analysis and error bars represent the variability between these duplicates. While there are substantial uncertainties in our measurements, we 
observed neither a seasonal cycle, nor an annual change in $\mathrm{Hg}_{\mathrm{T}}$ deposition over this period.

Although these are the first measurements of $\mathrm{Hg}_{\mathrm{T}}$ made at Summit, reactive mercury $\left(\mathrm{Hg}_{\mathrm{R}}\right)$ has been studied at this site in the past, both in the first seven meters of the snow and firn (Mann et al., 2004) and in the deep firn (Boutron et al., 1998). $\mathrm{Hg}_{\mathrm{R}}$ corresponds to the fraction of mercury bound in complexes that are easily reducible by $\mathrm{SnCl}_{2}$ or $\mathrm{NaBH}_{4}$. Examples include $\mathrm{HgCl}_{2}, \mathrm{Hg}(\mathrm{OH})_{2}$ and $\mathrm{HgC}_{2} \mathrm{O}_{4}$ (Lindqvist and Rodhe, 1985). Reactive mercury represents less than $10 \%$ of $\mathrm{Hg}_{T}$ in the Summit snowpack. Mann et al. (2004) reported a high variability of $\mathrm{Hg}_{\mathrm{R}}$ concentrations in the first $2 \mathrm{~m}$ of the snowpack, with values ranging from 0.25 to $0.68 \mathrm{ng}^{-1}$ (mean value of $\sim 0.46 \mathrm{ng}^{-1}$ ).

\subsection{GEM in the atmosphere}

We measured GEM levels in atmospheric air at Summit Station during summer 2005 and spring 2006. Concentrations were stable, and no atmospheric GEM depletion events were observed. Mean concentrations were $1.61 \pm 0.14 \mathrm{ng} \mathrm{m}^{-3}$ ( $\left.n=1102\right)$ from 27 May to 6 June 2006, and $1.80 \pm 0.14 \mathrm{ng} \mathrm{m}^{-3}(n=112)$ from 23 to 29 July 2005 . GEM atmospheric levels measured during both spring and summer at Summit were a bit higher than concentrations reported for Alert at the same season (Steffen et al., 2005). This slight difference $(\sim 10 \%)$ was not confirmed by intercalibrations and comparison measurements of the instruments used at Alert and Summit. However, the air masses at Alert and Summit have different origins: the chemical loading to the atmosphere above Summit is influenced by air masses arriving at high altitude (500 hPa) (Khal et al., 1997). Moreover, springtime displays a strong variability of GEM concentrations in the atmosphere at Alert due to the atmospheric mercury depletion events (AMDEs). These phenomena, leading to a complete depletion of GEM in the atmosphere, occur simultaneously with the post-solar sunrise destruction of ozone. Helmig et al. (2007b) investigated the surface ozone mixing ratio at Summit Station from 2000 to 2004 and reported concentrations ranging from $\sim 40$ to $\sim 70 \mathrm{ppbv}$ without any ozone depletion event. No atmospheric ozone and mercury depletion events were observed at Summit, indicating no strong variations in their atmospheric concentrations throughout the year.

\subsection{GEM from the top surface snow to $3 \mathrm{~m}$ depth}

\subsubsection{Variations in GEM concentrations with depth}

Evolution of GEM concentrations with depth, from the top surface to a depth of $30 \mathrm{~m}$, is presented in Fig. 3. The dashed line represents the mean atmospheric GEM concentration of $\sim 1.65 \mathrm{ng} \mathrm{m}^{-3}$, estimated from data obtained both during summer 2005 and spring 2006. At lower concentrations (left side of the dashed line) is the profile measured during spring

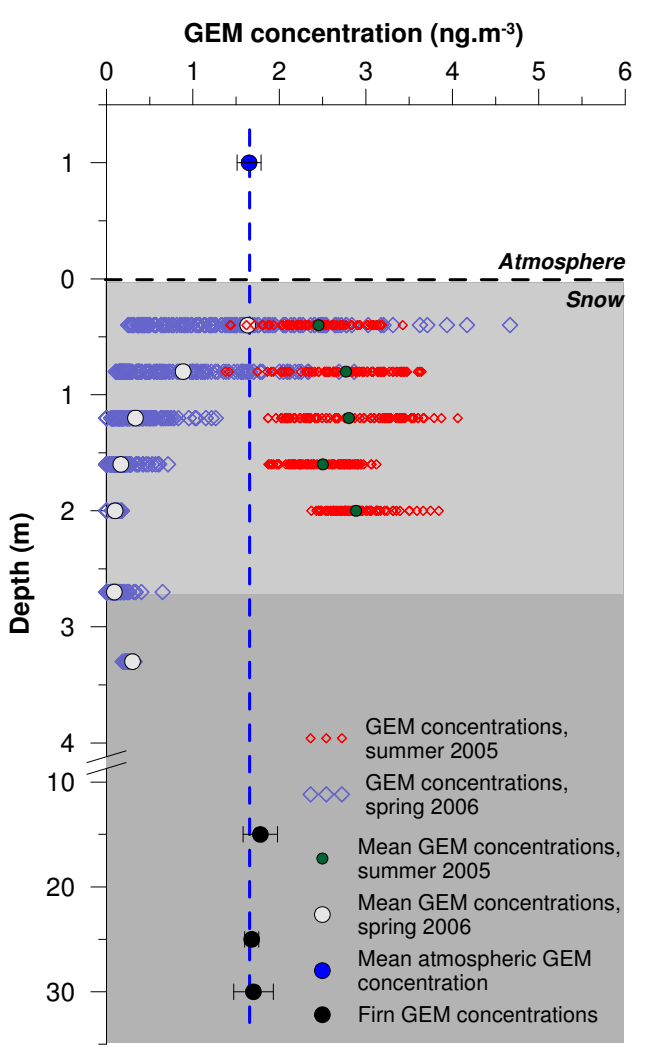

Fig. 3. GEM concentrations $\left(\mathrm{ng} \mathrm{m}^{-3}\right)$ from the atmosphere to $30 \mathrm{~m}$ depth in the firn at Summit Station. Data in the SIA from 40 to $330 \mathrm{~cm}$ depths were measured from 29 May to 6 June 2006 (blue) and from 19 to 27 July 2005 (red). Measurements at 15, 25 and $30 \mathrm{~m}$ depth were collected on 3 and 4 June 2006. The atmospheric value is a mean concentration covering the June and July sampling period.

2006. Higher concentrations correspond to the profile measured during summer 2005 (right side of the dashed line). For each depth, all of the data collected are graphed and the corresponding mean GEM concentrations at each depth are given with the solid and open circles. In spring 2006, we observed a decrease in the mean GEM concentration with depth in the snow interstitial air (SIA) with level close or below the atmospheric one. During summer 2005, mean GEM concentrations were always above the atmospheric level, increasing from $40 \mathrm{~cm}$ to $120 \mathrm{~cm}$ depths, and decreasing at a depth of $160 \mathrm{~cm}$. Finally, mean concentration at a depth of $200 \mathrm{~cm}$ was close to the one recorded at a depth of $140 \mathrm{~cm}$. The evolution of mean GEM concentrations in the SIA during spring 2006 presented a similar trend to that reported for Station Nord, (North Greenland) by Ferrari et al. (2004a). At this site, a seasonal snowpack $\sim 1 \mathrm{~m}$ thick was investigated, and an exponential decrease of GEM concentrations was observed from atmospheric levels at the snow surface to $0.1-0.2 \mathrm{ng} \mathrm{m}^{-3}$ at the bottom of the snowpack. Hence, GEM consumption at a depth of $100 \mathrm{~cm}$ in arctic snow has 


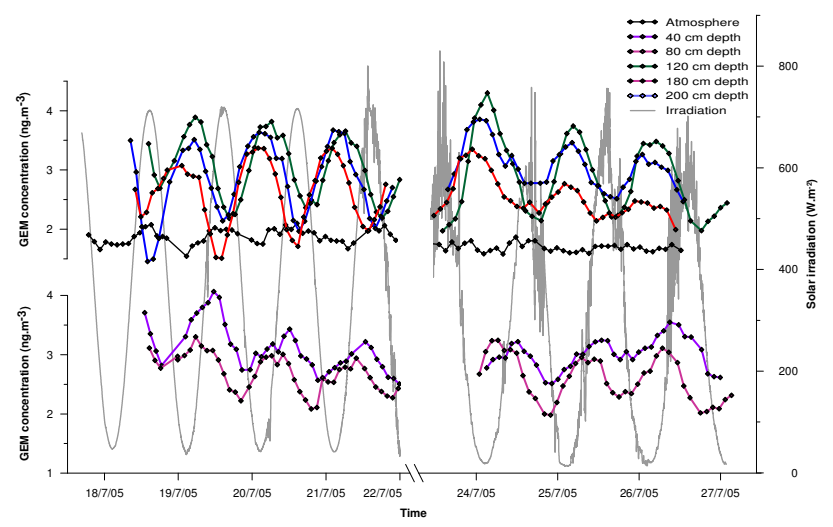

Fig. 4. GEM concentrations $1.5 \mathrm{~m}$ above the snow surface and at $40,80,120,160$ and $200 \mathrm{~cm}$ depths in the SIA, from 18 to 27 July 2005, at Summit Station. The grey line reports the global irradiation $\left(\mathrm{W} \mathrm{m}^{-2}\right)$.

been previously observed. On the other hand, we report for the first time an increase of mean GEM concentrations with depth in snow and firn air at Summit Station during summer 2005, but these measurements could be strongly influenced by sampler-induced advection, as discussed in Sect. 3.4.3.

\subsubsection{Daily variations in GEM concentrations}

Evolution of GEM concentrations with time in the SIA and above the snow surface, from 18 to 27 July 2005 (summer 2005), and from 29 May to 6 June 2006 (spring 2006), are reported in Figs. 4 and 5 respectively. As presented in the previous section, summer 2005 and spring 2006 differed strongly regarding the evolution of mean GEM concentrations with depth in the SIA. However, during both periods, GEM concentrations exhibited a diel variation anticorrelated to solar irradiation in the first two meters of the snowpack. We measured production and depletion of GEM in the SIA, with maximum concentrations at midnight and minimum concentrations at midday. GEM levels measured at 200 and $270 \mathrm{~cm}$ depths during spring 2006 were close to the detection limit of the 2537A Tekran analyzer, and the fluctuations observed were below $0.15 \mathrm{ng} \mathrm{m}^{-3}$, the uncertainty reported for this analyzer. Indeed we measured $0.09 \pm 0.08 \mathrm{ng} \mathrm{m}^{-3}(n=41)$ at a depth of $200 \mathrm{~cm}$, and $0.08 \pm 0.10 \mathrm{ng} \mathrm{m}^{-3}(n=117)$ at a depth of $270 \mathrm{~cm}$. At a depth of $330 \mathrm{~cm}$, the GEM concentration was monitored continuously during $48 \mathrm{~h}$ : no diel variation was observed, and levels were stable with a mean value of $0.27 \pm 0.04 \mathrm{ng} \mathrm{m}^{-3}(n=34)$. In summer 2005, diel variations of GEM concentrations were observed from the surface to a depth of $200 \mathrm{~cm}$. Of the many recordings, only very few measurements fell below the atmospheric level at a depth of $40 \mathrm{~cm}$; most measurements in the near-surface in July were higher than the ambient atmospheric concentration. Due to equipment maintenance, we were not able to collect data on 22 and 23 July. In the following section, we investigate the different roles of physical

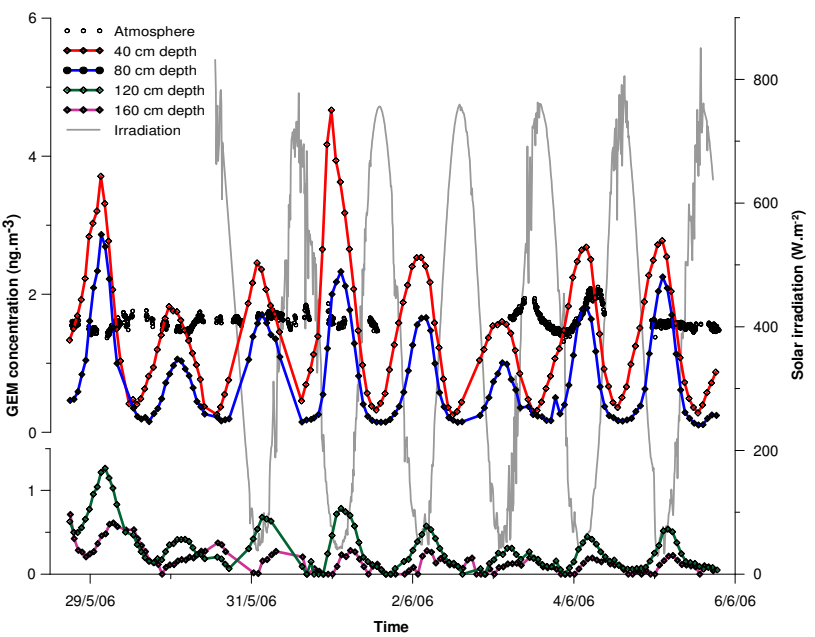

Fig. 5. GEM concentrations $1.5 \mathrm{~m}$ above the snow surface and at 40, 80, 120 and $160 \mathrm{~cm}$ depths in the SIA, from 29 May to 6 June 2006, at Summit Station. The grey line reports the global irradiation $\left(\mathrm{W} \mathrm{m}^{-2}\right)$.

processes and chemical mechanisms in the daily variations of GEM concentrations in the SIA.

\subsubsection{Chemical or physical processes in the SIA?}

Diel variations of GEM concentrations were observed both during spring and summer (see Figs. 4 and 5). Five possible phenomena could potentially explain the variations observed: i) adsorption of GEM on snow grains, ii) natural ventilation, iii) diffusion within the deeper snowpack, iv) chemical processes leading to destruction and/or production of GEM and v) advective flow induced by the sampling procedure. Due to the high adsorption energy of GEM on snow evaluated at $\sim 61 \mathrm{~kJ} \mathrm{~mol}^{-1}$ (Ferrari et al., 2004a), the adsorption of GEM is extremely reduced and cannot explain these observations. Similarly, natural ventilation could not induce the variation of GEM concentrations observed. Albert and Shultz (2002) showed at Summit Station that gas transport in high permeability layers $15 \mathrm{~cm}$ beneath the snow surface under low winds $\left(\sim 3 \mathrm{~m} \mathrm{~s}^{-1}\right)$ was not influenced by natural ventilation, but controlled by diffusion.

To identify the potential role of diffusion in the interstitial air in the snow and firn, we simulated the diffusion of the diel variation of GEM recorded in spring 2006 at a depth of $40 \mathrm{~cm}$. We first determined diffusion constants characterizing GEM and the firn structure at Summit Station. The GEM diffusivity in air at Summit Station $D_{(T, P)}^{\text {Surface }}$ was determined using the value reported by Massman (1999) corrected for Summit temperature and pressure (Schwander et al., 1988).

$D_{T, P}^{\text {Surface }}=D_{T_{0}, P_{0}} \times \frac{P_{0}}{P} \times\left(\frac{T}{T_{0}}\right)^{1.85}$ 
where $T_{0}=253.16^{\circ} \mathrm{K}, \quad P_{0}=1013.25 \mathrm{mbar}, \quad T=241^{\circ} \mathrm{K}$ and $P=675$ mbar. $T$ and $P$ are mean annual atmospheric values of temperature and pressure for the site of Summit. Equation (1) gives the GEM diffusivity in the atmosphere above the firn surface. To obtain the effective diffusivity of GEM in the SIA $\left(D_{\text {eff }}\right)$, we used the following relation:

$D_{\text {eff }}=\frac{\phi}{\tau} \times D_{(T, P)}^{\text {Surface }}$

where $\phi$ is the snow porosity determined using the densities of snow and ice:

$\phi=1-\frac{\rho_{\text {Snow }}}{\rho_{\text {Ice }}}$

$\tau$ is the firn tortuosity. The tortuosity of a porous medium represents the complexity of the pathway, and is commonly calculated as the ratio of the mean path length to the minimum possible (straight line) path length. Albert and Shultz (2002) reported that the tortuosity of the surface wind pack at Summit in June was $\sim 2.0$. A value of 2.0 is the maximum tortuosity value that can be considered in the first several meters of the snowpack, because the top $50 \mathrm{~cm}$ of snow is wind-pack, and is less permeable than the underlying layers at Summit, as can be seen in Fig. 2. Considering a tortuosity of 1.4-2.0 and a snow porosity of $\sim 0.7$, we obtained $D_{\text {eff }}$ for GEM of $0.06-0.08 \mathrm{~cm}^{2} \mathrm{~s}^{-1}$.

Diel cycles of GEM concentrations in the SIA showed a time shift with increasing depth both during summer (Fig. 4) and spring (Fig. 5), suggesting that diffusion was occurring. To better assess the transport of GEM by diffusion in the SIA, we modeled this physical process from 40 to $270 \mathrm{~cm}$ depths during spring 2006. In this model, we used GEM spring measurements at a depth of $40 \mathrm{~cm}\left(\mathrm{GEM}_{40}\right)$ and a constant concentration of $0.1 \mathrm{ng} \mathrm{m}^{-3}$ at a depth of $270 \mathrm{~cm}$ as boundary conditions. The modeled diffusion of $\mathrm{GEM}_{40}$ deeper in the snowpack is shown on Fig. 6. A comparison of modeled data and measurements is also represented. Peak concentrations from field data exhibit a slight shift in time when depth increases but modeling results show that this shift should be larger if only diffusion took place in the SIA. This effect could be due of induced air advection in the firn, as we discuss in the following paragraph.

Albert et al. (2002) showed that interstitial air sampling in snow with sampler flow rates of $11 \mathrm{~min}^{-1}$ (and higher) draws in a substantial amount of ambient air into the sampler, even when one assumes that the sampler has perfect contact with the surrounding snow. Thus, we investigated the role of induced interstitial advection in the shallow firn. Using the multidimensional model (Albert, 1996; Albert et al., 2002), along with the measured permeability profile depicted in Fig. 1 for the permeability of the top two meters for spring 2006, and the published permeability profile deeper in the firn at Summit (Albert and Shultz, 2002), we investigated the impacts of sampler-induced advection on the concentration profiles measured in the firn air during spring 2006. Using a sampler intake rate of $11 \mathrm{~min}^{-1}$ for each simulation, Fig. 7 depicts the air flow patterns when the intake is at depths of 40,120 , and $160 \mathrm{~cm}$ in the firn. The closer the intake is to the atmosphere/snow interface, the more air is drawn vertically down through the surrounding snow into the sampler intake, thus diluting the sampled air at the sampled depth with air from above. This is clearly evident when the sample intake is at a depth of $40 \mathrm{~cm}$ (Fig. 7a); most of the air into the inlet is coming directly down from the near-surface snow. As the inlet gets deeper, the contribution from the snow-air interface decreases, and the contribution from nearby permeable layers (whether above or below the inlet) increases. Considering the inlet at a depth of $120 \mathrm{~cm}$ (Fig. 7b), there is still surface air coming down, but a greater part of the sample comes from the high-permeability layer locate between $50-95 \mathrm{~cm}$ depths in the snow. At a depth of $160 \mathrm{~cm}$ (Fig. 7c), much of the air sampled comes from the high-permeability layer above the intake: this high-permeability layer serves as a channel for lateral flow in the firn. Sampler-induced advection transports down photochemically-induced changes in GEM concentrations from the near-surface snow. On one hand, we assume that diel cycles observed from 80 to $160 \mathrm{~cm}$ depths during spring 2006 are due to sampler-induced advection. The decrease with depth of the amplitude of the diel GEM variations is consistent with our modeling, showing less influence of the forced advection as depth increases. We note that dilution/mixing of interstitial air measurements by flow samplers is not unique to this study; in fact it is an unavoidable artifact of all firn air measurements that have been carried out by flow samplers to date (Albert et al., 2002; Dominé et al., 2008). On the other hand, sampler-induced advection could not explain the decrease in minimum GEM concentrations with depth measured close to midday. Diffusion modeling, reported on Fig. 5, could not reproduce either this destruction of GEM, which may reflect chemical mechanisms involving GEM from 40 to $270 \mathrm{~cm}$ that will be discussed in the following section.

Snow permeability data were not available for summer 2005, therefore we could not model the impact of sampler induced advection on the GEM data. However, the diffusion model used previously to investigate GEM data from spring 2006 (Fig. 6) was applied to the data collected during summer 2005, and demonstrated that diffusion of GEM was too slow to explain the diel cycles deeper in the SIA. Similarly to spring data, we assume that diel GEM variations below a depth of $80 \mathrm{~cm}$ could be an artifact due to sampler-induced advection. Forced advection could also lead to an underestimation of GEM concentrations in the first meter due to the mixing of low-concentrated air from the atmosphere and high concentrated air from the SIA. Thus, the increase of the mean GEM concentrations with depth during summer 2005 could not be explained by diffusion, but may be an artifact of sampler-induced advection. Dark chemical production of GEM should also be considered as a possible mechanism for the observed increase in GEM concentrations. 


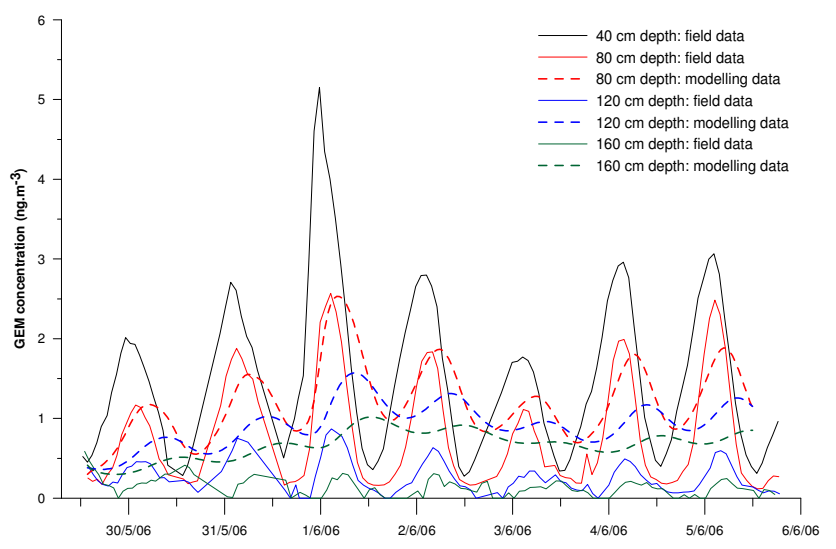

Fig. 6. Modeling of diffusion with depth of GEM variations observed at a depth of $40 \mathrm{~cm}$ in June 2006. The dashed lines represent the field observations, while the full lines represent the expected variations if only diffusion was happening in the SIA.

In summary, measurements in the field when compared to gas transport modeling lead to the evidence that natural diffusion was not the main process driving the evolution of GEM concentrations in the SIA. On the other hand, photochemical changes in GEM that occur in the top centimeters to tens of centimeters of snow are likely advected down into the sampler, giving the appearance that photochemical reactions are occurring deeper in the snow than is actually the case. Despite this sampler-induced artifact, there is evidence of chemical processes involving GEM in the SIA, with both photolytic mechanisms close to the surface and dark processes in the first three meters of the snowpack.

\subsubsection{Chemical mechanisms within the snowpack}

The photochemical processes in snow and the exchanges of reactive trace gases between the SIA and the Atmospheric Boundary Layer (ABL) have been largely investigated at Summit Station (Dibb et al., 2007). Galbavy et al. (2007) measured irradiance in the snow and firn at Summit, and found actinometry e-folding depths near $12 \mathrm{~cm}$. Less than $2 \%$ of monochromatic light penetrates deeper than the top half-meter at Summit. Thus, photochemistry can directly play a role from the top surface to $\sim 60 \mathrm{~cm}$ depth in the snow at Summit. In this area, defined as the sunlit snow, diel variations of GEM observed during spring and summer in the SIA were probably the result of the co-existence of GEM oxidation and $\mathrm{Hg}$ (II) reduction. These two competitive phenomena have already been observed in coastal snowpacks in the Arctic (Dommergue et al., 2003b; Ferrari et al., 2004b). In our case, oxidation was predominant during spring and $\mathrm{Hg}(\mathrm{II})$ reduction was predominant during summer. According to e-folding depth values reported by Gavaldy et al. (2007), there is no evidence that significant, naturally-occurring photochemical reactions involving
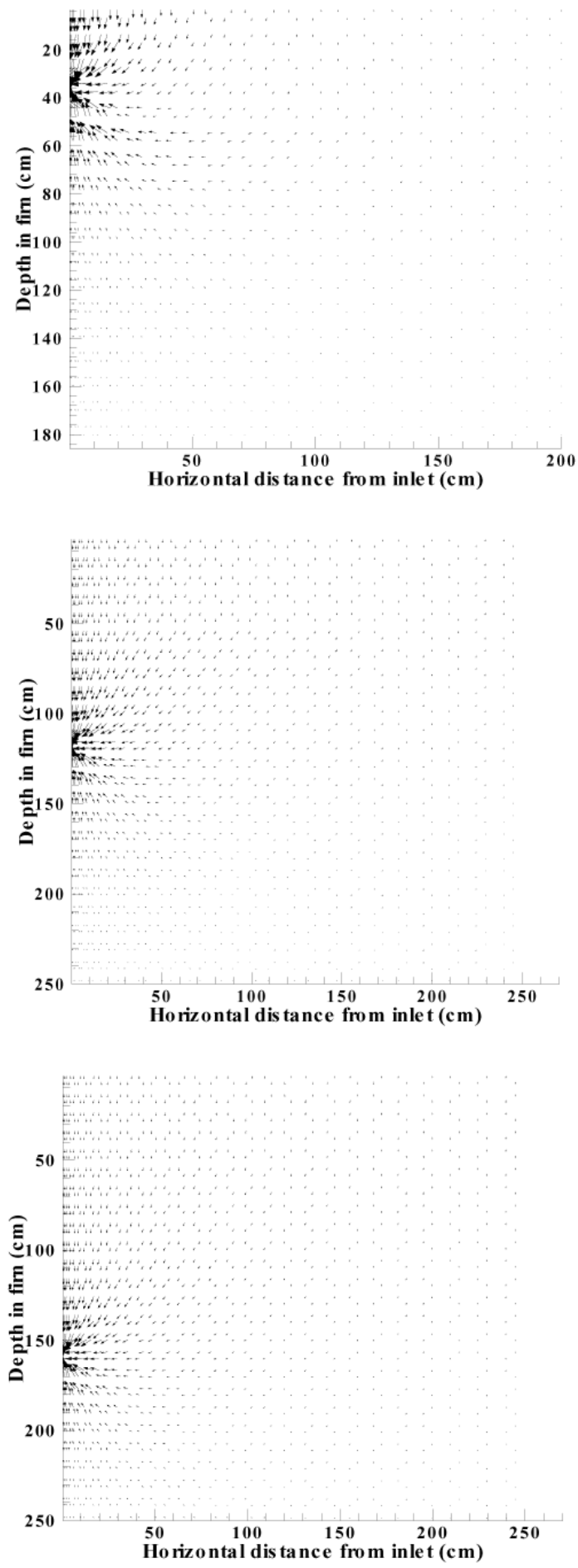

Fig. 7. Modeled air flow patterns into the sampler intake, given the measured permeability profile at Summit, when the intake is at depths of 40,120, and $160 \mathrm{~cm}$ in the firn. Samples drawn from the top two meters of firn include firn air that has undergone photochemical reactions at shallower depths in the snow. 
GEM could occur below $\sim 60 \mathrm{~cm}$ depth. However, at Dome $\mathrm{C}$ (Antarctica), irradiance attenuation in the shallow firn depends on the snow layers considered: at higher depths, Warren et al. (2006) observed a lower irradiance attenuation related to an increase in snow grain size. A similar study is necessary at Summit Station to better characterised the photochemical processes in the snowpack. Assuming that light does not penetrate below $\sim 60 \mathrm{~cm}$ depth, the diel variation of GEM concentrations from 80 to $200 \mathrm{~cm}$ depths in the SIA is probably due to the transport of the photochemically-induced gas composition in the top half-meter to deeper depths by the sampler flow, as shown by our modeling (see Fig. 7). This effect occurred both during summer 2005 and spring 2006. However, the decrease of mean GEM levels during spring 2006, and their stabilization to zero (see Fig. 3) from 200 to $270 \mathrm{~cm}$ could not be explained by the transport of the depleted air but only by dark oxidation processes in the SIA. The active photochemistry involving both GEM and $\mathrm{Hg}$ (II) complexes implies that one must exhibit great caution when using $\mathrm{Hg}_{\mathrm{R}}$ and $\mathrm{Hg}_{\mathrm{T}}$ profiles to infer depositional histories. $\mathrm{Hg}$ (II) species could be perturbed by post-deposition processes occurring close to the surface, leading to $\mathrm{Hg}_{R}$ or $\mathrm{Hg}_{\mathrm{T}}$ profiles in the firn that would not be simply linked to the history of mercury deposition on the surface. In the next sections we discuss the photolytic and dark mechanisms which could be involved in the destruction and production of GEM.

\subsubsection{GEM depletion within the snowpack}

In the sunlit snow, we observed GEM depletion with concentrations lower than atmospheric ones and a diel evolution which was anti-correlated to solar irradiation during both summer 2005 and spring 2006. During spring 2006, we also observed a depletion of GEM in the SIA below the sunlit zone, with GEM concentrations close to zero from 200 to $270 \mathrm{~cm}$ (see Fig. 3). Thus, both photolytic and dark oxidation of GEM were occurring in the SIA at Summit.

Using backward transport model simulations, Sjostedt et al. (2007) showed that the boundary layer at Summit could be periodically impacted by halogens, and the bromine mixing ratio in the SIA at Summit was estimated at $1-4$ ppbv by Peterson et al. (2001). Br is probably the most efficient oxidant for GEM in the Arctic troposphere (Ariya et al., 2004; Skov et al., 2004), although $\mathrm{BrO}^{\bullet}$ could also be an active oxidant for GEM (Raofie and Ariya, 2004). Thus, GEM depletion within the snowpack could be the result of homogenous and/or heterogeneous chemistry with Br radicals (Ferrari et al., 2004b; Goodsite et al., 2004). The following mechanism has been proposed by Goodsite et al. (2004):

$\mathrm{Hg}^{\circ}+\mathrm{Br}^{\bullet} \rightarrow \mathrm{HgBr}^{\bullet}$

$\mathrm{HgBr}^{\bullet}+\mathrm{Br}^{\bullet} \rightarrow \mathrm{HgBr}_{2}$

These authors demonstrated that a recombination of $\mathrm{Hg}^{\circ}$ with $\mathrm{Br}^{\bullet}(\mathrm{R} 1)$, followed by the addition of a second radical $\mathrm{Br}^{\bullet}(\mathrm{R} 2)$ was able to explain the observed rate of $\mathrm{Hg}^{\circ}$ removal during AMDEs. Radicals $\mathrm{I}^{\bullet}$ and $\mathrm{OH}^{\bullet}$ could also interact with $\mathrm{HgBr}^{\bullet}$, but their concentrations within the snowpack are to low for these compounds to be considered. $\mathrm{Br}_{2}$ is also an oxidant for GEM according to the following reaction:

$\mathrm{Hg}^{\circ}+\mathrm{Br}_{2} \rightarrow \mathrm{HgBr}_{2}$

However, the rate constant for reaction (R3) is much lower (by a factor $\sim 10^{5}$ ) than the rate constants for (R1) and (R2) (Ariya et al., 2002; Goodsite et al., 2004). Since Reactions (R1), (R2) and (R3) are exothermic in gas and aqueous phases (Tossel, 2003), they could occur in a dark environment if $\mathrm{Br}^{\bullet}$ radicals or $\mathrm{Br}_{2}$ are available.

Modeling and measurements of photolyzable bromine $\left(\mathrm{Br}_{2}, \mathrm{BrCl}, \mathrm{HOBr}\right)$ and bromine radicals at Alert, Canada, showed that the snowpack is a bromine source (Tang and McConnell, 1996). Foster et al. (2001) reported $\mathrm{Br}_{2}$ concentrations in the SIA at Alert, Canada, that were the double of those measured in the overlying air during the sunlight period, which provides evidence for the production of $\mathrm{Br}_{2}$ in natural snowpacks. There are now several observations suggesting that halogen chemistry may also be important at Summit: Swanson et al. (2007) provided evidence for production of alkyl halides in the SIA, and Sjostedt et al. (2007) suggested that HOx chemistry could be linked to halogen oxides at Summit Station. In the lower atmosphere, $\mathrm{Br}^{\bullet}$ radicals are formed by $\mathrm{Br}_{2}$ photodissociation at wavelengths below $620 \mathrm{~nm}$. Such wavelengths are available in the top centimeters of the snowpack at Summit Station (Galbavy et al., 2007). In July at Summit, Peterson and Honrath (2001) measured diel variations of ozone concentrations at a depth of $30 \mathrm{~cm}$ with minimum concentrations at midday, and levels close to atmospheric ones during the night. They demonstrated that only destruction by bromine radicals is sufficiently efficient to explain such rapid processes. Such ozone depletions are similar to GEM measurements we report for the sunlit zone both during summer and spring. We finally assume that the mechanisms involved in the destruction of GEM in the sunlit snow (from the surface to $\sim 60 \mathrm{~cm}$ depth) are similar to the ones happening during AMDEs and ODEs in the polar atmosphere during spring, as previously suggested (Ferrari et al., 2004b): GEM is actively converted to its oxidized form $\mathrm{Hg}(\mathrm{II})$ when solar irradiation is strong enough to produce $\mathrm{Br}^{\bullet}$ by the photolysis of $\mathrm{Br}_{2}$.

Deeper, the snowpack may also act as a source of $\mathrm{Br}_{2}$, even if there is no light. Oum et al. (1998) reported laboratory measurements suggesting that the oxidation of $\mathrm{Br}^{-}$ions by ozone at the surface of the snow crystals could produce $\mathrm{Br}_{2}$ in the dark. These authors proposed the following reactions:

$$
\begin{aligned}
& \mathrm{O}_{3}+\mathrm{Br}^{-} \rightarrow \mathrm{BrO}^{-}+\mathrm{O}_{2} \\
& \mathrm{BrO}^{-}+\mathrm{H}^{+} \rightarrow \mathrm{HOBr} \\
& \mathrm{HOBr}+\mathrm{H}^{+}+\mathrm{Br}^{-} \rightarrow \mathrm{Br}_{2}+\mathrm{H}_{2} \mathrm{O}
\end{aligned}
$$


This mechanism is consistent with field observations reported before the polar sunrise at Alert by Foster et al. (2001). These authors reported the simultaneous depletion of ozone and production of $\mathrm{Br}_{2}$ in the SIA. Recently, Helmig et al. (2007a) reported $\mathrm{O}_{3}$ measurements in the SIA at Summit from April to June 2004. These authors did not observed any ozone destruction in the SIA during the polar night (beginning of April) but they did not investigated ozone below a depth of $60 \mathrm{~cm}$. Deeper measurements are necessary to conclude whether or not dark ozone oxidation occurred during this period of the year. On the other hand, they reported permanent minimum ozone levels at a depth of one meter for June. Such a decrease in concentration with depth cannot be explained by diffusion or sampler-induced advection. Considering that the actinic flux is null at this depth in the Summit snowpack (Galbavy et al., 2007), dark destruction of ozone in the SIA must be occurring. We assume that such dark oxidation reported for $\mathrm{O}_{3}$ at Alert by Foster et al. (2001) also occurred in the SIA at Summit Station according to the mechanisms described previously (R4-R5-R6). This destruction of ozone is a source of $\mathrm{Br}_{2}$, which becomes available for GEM oxidation in the SIA via Reaction (R3).

More measurements during different seasons are now necessary to better understand the dark chemical processes involving both ozone and GEM. During summer 2005, we did not observe dark destruction of GEM directly, but rather diffusion of GEM produced in the sunlit snow through deeper layers. Sampling-induced artifacts could have also hidden this process.

\subsubsection{GEM production in the snowpack}

GEM photo-production in the shallow firn was observed both during spring and summer, from the top surface to a depth of $\sim 60 \mathrm{~cm}$ where light could penetrate. GEM production processes were much more active relative to oxidation during the summer rather than during spring. GEM production was previously reported in interstitial air of both polar (Dommergue et al., 2003b; Ferrari et al., 2004b) and mid-latitude snowpacks (Poulain et al., 2004; Faïn et al., 2007). Most authors assumed that such production is the result of direct photodissociation of $\mathrm{Hg}$ (II) complexes. This reduction mechanism was also observed in water solutions (Xiao et al., 1994) and was suggested to occur in snow (Lalonde et al., 2002; Lalonde et al., 2003). GEM could also be produced by the reduction of $\mathrm{Hg}$ (II) complexes by photochemically produced compounds. Hydroperoxyl radical $\left(\mathrm{HO}_{2}^{\bullet}\right)$ was proposed as a potential reductant of $\mathrm{Hg}(\mathrm{II})$ in liquid water (Lin and Pehkonen, 1999). This hypothesis has to be considered carefully, since a recent study based on thermodynamic considerations showed that reduction of $\mathrm{Hg}$ (II) by $\mathrm{HO}_{2}^{\bullet}$ radicals should be of minor importance (Gardfeldt and Jonsson, 2003). Sjostedt et al. (2007) reported the first measurements of peroxy radicals above the Summit snowpack. The majority of $\mathrm{HO}_{2}^{\circ}$ radicals in the SIA are generated via the photolysis of $\mathrm{O}_{3}$,
$\mathrm{H}_{2} \mathrm{O}_{2}$, $\mathrm{HONO}$ and $\mathrm{CH}_{2} \mathrm{O}$. Thus $\mathrm{HO}_{2}^{\bullet}$ concentrations exhibit a diel pattern with maximum values at midday, but levels above zero at night. Humic acids may also play a central role in the degradation of $\mathrm{Hg}(\mathrm{II})$ molecules by producing reactive species. These mixtures of organic macromolecules can transfer electrons to species adsorbed on their surfaces when irradiated over broad spectral regions.

Laboratory flux chamber measurements indicated that GEM is first driven by solar radiation (especially UVA and UVB radiation), and then could be enhanced when liquid water is observed in the snowpack (Dommergue et al., 2007; Faïn et al., 2007). Global irradiation and air temperatures were higher during summer 2005 as compared to spring 2006: the evolution of these two environmental parameters from spring to summer favored an increase in the photoproduction processes of GEM.

Our 2005 data showed an increase in the mean GEM concentration with depth, and a maximum was measured at a depth of $120 \mathrm{~cm}$. This could be explained by samplerinduced advection from concentrated layers located close to the surface. However, dark production of GEM could also occur, as previously reported from snow samples collected in a mid-latitude snowpack (Lalonde et al., 2003), inside an alpine snowpack (Faïn et al., 2007) and inside an arctic snowpack (Ferrari et al., 2004b).

\subsubsection{Seasonal variations of GEM concentration}

Environmental parameters such as irradiation and temperature, as well as the snow and the snow air compositions, evolved from spring to summer and led to a change in the relative importance of both GEM destruction and GEM production mechanisms in the SIA at Summit. However, we observed mean GEM concentrations in the SIA that were lower during spring and higher during summer than the atmospheric level. This suggests that GEM concentrations, up to a depth of three meters in the SIA, could exhibit a yearly variation with low concentrations during spring and higher concentrations during summer. However, no measurements were available for winter time. Using GEM concentrations collected from 15 to $30 \mathrm{~m}$ depths and diffusion modeling, we first investigated if any seasonal variations in GEM concentrations close to the surface could affect GEM levels in the deep firn air, thereby affecting the long-term record that is represented by the deep firn air. We then characterized the mean value and the amplitude of the seasonal variation expected in the shallow firn.

\subsection{GEM in the firn air}

\subsubsection{Do chemical processes exist in the deep firn air?}

GEM concentrations measured at 15,25 and $30 \mathrm{~m}$ depths in the firn were respectively $1.78 \pm 0.17 \mathrm{ng} \mathrm{m}^{-3} \quad(n=6)$, $1.68 \pm 0.08 \mathrm{ng} \mathrm{m}^{-3} \quad(n=2)$ and $1.70 \pm 0.17 \mathrm{ng} \mathrm{m}^{-3} \quad(n=6)$. 
These measurements were taken at depths too high to be significantly impacted by sampler-induced air flow from the snow surface down to these levels; rather, these concentrations represent interstitial air from the nearest permeable layer. These values are all close to the atmospheric level of $\sim 1.65 \mathrm{ng} \mathrm{m}^{-3}$. As discussed in Sect. 3.4.2., dark destruction of GEM was occurring in the SIA close to the surface. Such processes obviously do not exit in the firn at depths of 15 to $30 \mathrm{~m}$, because the GEM concentrations observed are not null. However, the temperature at both 15 and $2 \mathrm{~m}$ depths are similar during spring, and close to the mean annual temperature of the site (i.e. $\sim-32^{\circ} \mathrm{C}$ ). We assume that the source of $\mathrm{Br}_{2}$ required for dark GEM destruction no longer exists in the firn air at a depth of $15 \mathrm{~m}$ and below. To our knowledge, measurements of ozone concentrations have never been reported for deep polar firn air, but $\mathrm{O}_{3}$ is a rather reactive gas which is not preserved in the air bubbles trapped in ice cores. The sinks of ozone are multiple, in the sunlit snow as well as in dark conditions. The atmospheric sources of ozone are much more limited and always require solar radiation. Thus, we suggest that the entire firn air column from a depth of $15 \mathrm{~m}$ to the bottom could exhibit null concentrations of ozone, and consequently null $\mathrm{Br}_{2}$ concentrations, an oxidant for GEM in dark conditions.

\subsubsection{Firn structure and modeling}

Figure 8 presents a conceptual model of the firn at Summit Station. We can think of the firn as having three primary zones: the chemical zone (CZ), the diffusion zone (DZ) and the lock-in zone. The chemical zone extends from the surface to $2.7 \mathrm{~m}\left(z_{C}\right)$ and GEM levels within this zone are determined by both chemical and physical processes. These are discussed in detail in the previous section. Daily variations of GEM concentrations in the near-surface snow air lead to bi-directional fluxes between the shallow firn and the lower atmosphere. Below $2.7 \mathrm{~m}$ depth, we observed an increase in GEM concentrations during spring 2006. This evolution could be explained by a slowdown or a stop of the chemical processes involving GEM, combined with diffusion from deeper snow layers. The diffusion zone extends from the bottom of the chemical zone to the top of the lock-in zone, and is comprised of an openly porous and permeable matrix in which the air's composition is determined solely by physical processes (as shown in Sect. 3.5.1., there is no chemical alteration of GEM below $z_{C}$ ). The diffusion zone ends at the top of the lock-in zone $\left(z_{D}\right)$. Within the lock-in zone, impermeable winter layers prevent the vertical diffusion of air, but persistent open porosity in the summer layers allows the extraction of samples (Martinerie et al., 1992). At still-greater depths, when the overburden is sufficient, all pores become closed and air can no longer be extracted. This defines the firn-ice transition.

We used a 1-D forward model developed by Rommelaere et al. (1997) to understand how the variations of GEM con-

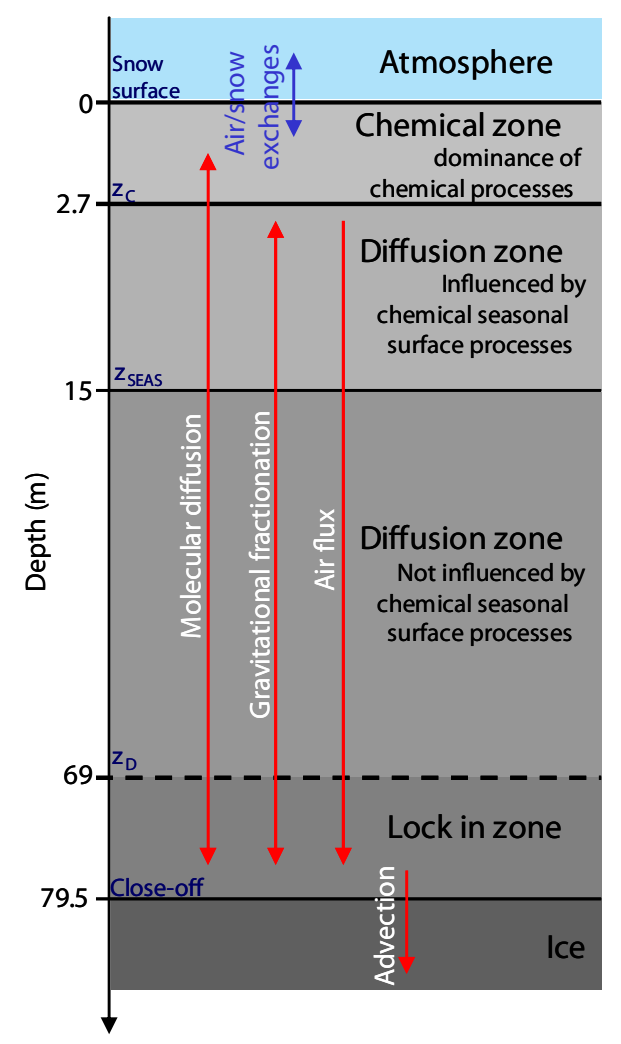

Fig. 8. Schematic view of the firn at Summit Station. Chemical processes involving GEM were observed in the Chemical Zone close to the surface. Below, the Diffusion Zone is characterized by physical transport mechanisms of GEM.

centrations occurring in the chemical zone could influence the GEM levels recorded in the air of the diffusion zone. Diffusion zone processes taken into account to simulate GEM transport were molecular diffusion, gravitational fractionation, and a downward air flux due to bubble closure sequestering air from open pores (see Fig. 8). This sequestered air must be replaced by air coming from the upper part of the firn, thus creating a downward flux. Surface temperature and accumulation rate were set to their present day values and assumed to be constant throughout the model run. We used firn structure parameters (density and closed porosity) from EUROCORE drilling (Schwander et al., 1993). Free-air diffusivity of GEM is given by Eq. (1) while Eq. (2) gives the diffusivity of GEM within the firn (i.e. $D_{\text {eff }}$, see Sect. 3.4.3). Deff depends on the firn tortuosity which increases progressively with depth. A null value of the ratio $1 / \tau$ at the top of the lock-in zone means that diffusion ceases at this depth. In short, the GEM effective diffusivity decreases from the snow surface value to zero at the close-off. We used tortuosity data reconstructed from $\mathrm{CO}_{2}$ record to determine the GEM $D_{\text {eff }}$ profile at Summit. See Fabre et al. (2000) for a more complete description of the method. 


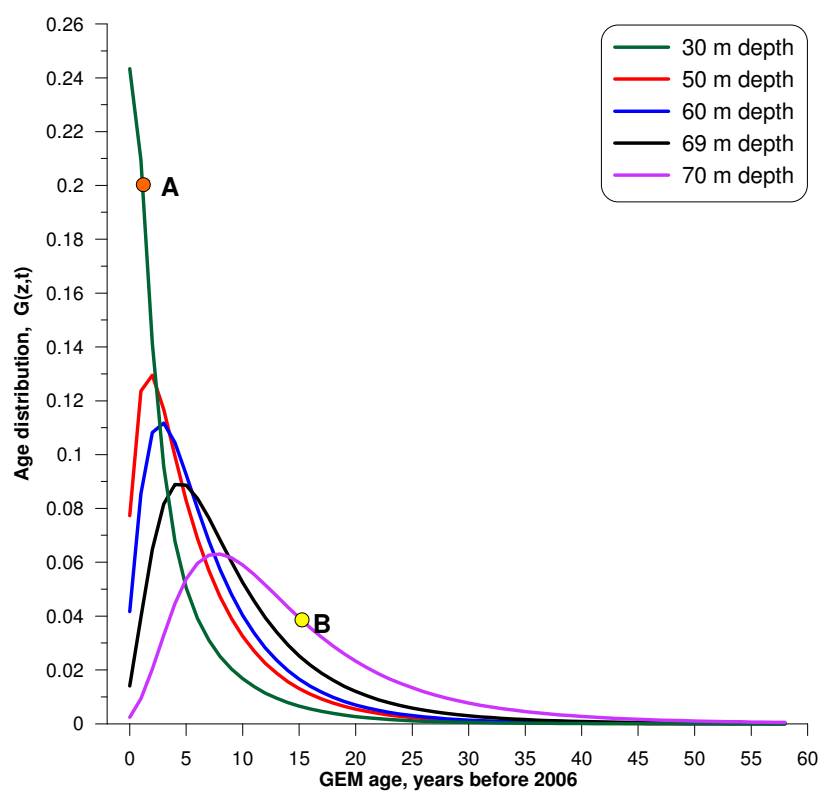

Fig. 9. GEM age distributions modeled at Summit Station indicating the percentage of the air with a given age for different depths in the firn.

\subsubsection{Age distribution}

Due to transport processes, the firn air at a given depth is not characterized by a single age, but by a distribution of ages (Schwander et al., 1993; Trudinger et al., 2002). We used our diffusion model to generate age distributions $G(z, t)$ of GEM. This approach has been used in various studies for a variety of gases with seasonal atmospheric cycles (Trudinger et al., 2002; Montzka et al., 2004; Assonov et al., 2007). The distribution for depth $z$ represents the relative contribution of different ages, where $\sum G(z, t) \equiv 1$. The age distributions at the depths of $30 \mathrm{~m}, 40 \mathrm{~m}, 50 \mathrm{~m}, 60 \mathrm{~m}, 69 \mathrm{~m}$ and $70 \mathrm{~m}$ are shown in Fig. 9. For example, point A indicates that $20 \%$ of GEM in the firn air at a depth of $30 \mathrm{~m}$ was in the atmosphere 2 years ago. Point B shows that $4 \%$ of GEM at a depth of $70 \mathrm{~m}$ is 15 years old. Above $70 \mathrm{~m}$, the distributions show nonzero values for the first year (for example, $\sim 4 \%$ at a depth of $60 \mathrm{~m}$ ). At $70 \mathrm{~m}$ and below, air is at least two years old. Consequently, the annual variations of GEM concentrations at the bottom of the chemical zone (depth $z_{C}$ ) cannot influence the firn air record below $70 \mathrm{~m}$. In short, GEM values below a depth of $70 \mathrm{~m}$ record the annual mean concentrations of the bottom of the $\mathrm{CZ}$.

For the firn air above $70 \mathrm{~m}$, we have to examine to which extent GEM variations in the CZ influence the GEM concentrations that are measured deeper. Using an intuitive approach, we perceive that the amplitude of the variations of GEM concentrations in the $\mathrm{CZ}$ decreases as the depth increases. Indeed, GEM diffusion takes longer as the air is deeper. For a better estimate of the diffusion of GEM varia- tions in the $\mathrm{CZ}$, we can adapt our transport model using different variation scenarios. We modeled their diffusion from the bottom of the $\mathrm{CZ}$ into the diffusion zone and compare this data to our field measurements.

\subsubsection{Downward diffusion of seasonal GEM variations}

As discussed in Sect. 3.4.5, GEM concentrations were stable in the atmosphere, but showed seasonal variations in the firn down to $z_{C}(2.7 \mathrm{~m})$ due to chemical processes and transport. These variations have an influence even below the chemical zone as they diffuse downward. However, due to decreasing diffusivity of the firn with depth, the amplitude of the seasonal GEM cycle also steadily decreases with depth, vanishing completely at a depth of $70 \mathrm{~m}$ (see Sect. 3.5.2). In order to understand the downward propagation of this seasonal signal through the diffusion zone, we simulated seven different seasonal cycles and compared them to firn-air observations between 15 and $30 \mathrm{~m}$ depths. The cycles we considered are shown in Fig. 10 and are composed of three distinct modes: constant concentrations close to the atmospheric background, periods with elevated GEM concentrations relative to atmospheric background and periods with depleted GEM concentrations relative to background. A constant concentration of $\sim 1.65 \mathrm{ng} \mathrm{m}^{-3}$ at the bottom of the chemical zone will arise if there is no chemistry in the shallow firn, or if there is equilibrium between production and destruction of GEM. Concentrations higher than atmospheric values occur when production processes dominate, as we observed during summer 2005. GEM concentrations below atmospheric levels will occur when oxidation exceeds production in the shallow firn, as we observed during spring 2006. All cycles were run for 16 years with a time step of 7.3 days. The age distribution (see Fig. 9) shows that $98 \%$ of the firn air is between 0 to 16 year old at a depth of $30 \mathrm{~m}\left(\sum_{t=0}^{16} G(30, t)=98 \%\right)$. For each of the scenarios described in Fig. 10, we calculated the depth $z_{\text {SEAS }}$ at which the amplitude of any GEM variation is less than $0.15 \mathrm{ng} \mathrm{m}^{-3}$, the uncertainty of our GEM analyzer. These values are presented in Table 1 . The location of $z_{\text {SEAS }}$ depends on both the amplitude of the GEM variations and the length of the constant concentration period (with GEM level of $\sim 1.65 \mathrm{ng} \mathrm{m}^{-3}$ ). Table 1 also includes the concentration of GEM at $z_{\text {SEAS }}$. Below $z$ SEAS, the GEM variations originating in the top layers of the snowpack are no longer observable. As shown by scenario 1, 2 and 3, an increase of the amplitude between maximum and minimum concentrations leads to an increase in the depth $z_{\text {SEAS }}$. An increase in the period with stable concentrations (of about $\sim 1.65 \mathrm{ng} \mathrm{m}^{-3}$ ) reduces $z_{\text {SEAS }}$ (compare cycles 2, 6 and 7). As expected, for all cycles, concentrations at $z_{S E A S}$ are close to the mean concentration at the bottom of the chemical zone. While the different trial cycles do lead to a range of values for $z$ SEAS, none has any influence on the firn air below a depth of $35 \mathrm{~m}$.

Using our observations from 15 to $30 \mathrm{~m}$ depths, we are able to further constrain the shape of the seasonal GEM cycle 
Table 1. Characteristics of GEM diffusion in the deeper firn of the scenarios presented in Fig. 6. $z_{D}$ is the depth where fluctuations induced by surface scenario are lower than $0.15 \mathrm{ng} \mathrm{m}^{-3}$. We also report GEM concentration at this depth $z_{D}$.

\begin{tabular}{|c|c|c|c|c|c|c|c|}
\hline Scenario & Description & $\begin{array}{l}\text { Annual mean GEM } \\
\text { concentration } \\
\left(\mathrm{ng} \mathrm{m}^{-3}\right)\end{array}$ & $\begin{array}{l}\text { Max GEM } \\
\text { concentration } \\
\left(\mathrm{ng} \mathrm{m}^{-3}\right)\end{array}$ & $\begin{array}{l}\text { Min GEM } \\
\text { concentration } \\
\left(\mathrm{ng} \mathrm{m}^{-3}\right)\end{array}$ & $\begin{array}{l}\text { Lenght of the period } \\
\text { with constant GEM } \\
\text { concentrations (months) }\end{array}$ & $\begin{array}{c}Z_{\text {seas }} \\
(\mathrm{m})\end{array}$ & $\begin{array}{c}\text { GEM concentration } \\
\text { at } Z_{\text {seas }} \\
\left(\mathrm{ng} \mathrm{m}^{-3}\right)\end{array}$ \\
\hline 1 & GEM production $>$ GEM destruction & 2.11 & 4.6 & 0.6 & 2 & 35.5 & 2.17 \\
\hline 2 & GEM production = GEM destruction & 1.65 & 2.9 & 0.1 & 2 & 31.5 & 1.64 \\
\hline 3 & GEM oxidation > GEM destruction & 1.37 & 2.1 & 0.2 & 2 & 28.7 & 1.4 \\
\hline 4 & Only GEM production & 2.26 & 1.6 & 2.9 & 2 & 26.7 & 2.31 \\
\hline 5 & Only GEM destruction & 0.94 & 1.6 & 0.1 & 2 & 26.7 & 0.95 \\
\hline 2 & Large annual variation & 1.65 & 2.9 & 0.1 & 2 & 31.5 & 1.64 \\
\hline 6 & Mean annual variation & 1.65 & 2.9 & 0.1 & 6 & 23.7 & 1.63 \\
\hline 7 & Variation expected on the field & 1.65 & 2.9 & 0.1 & 8 & 15 & 1.57 \\
\hline
\end{tabular}

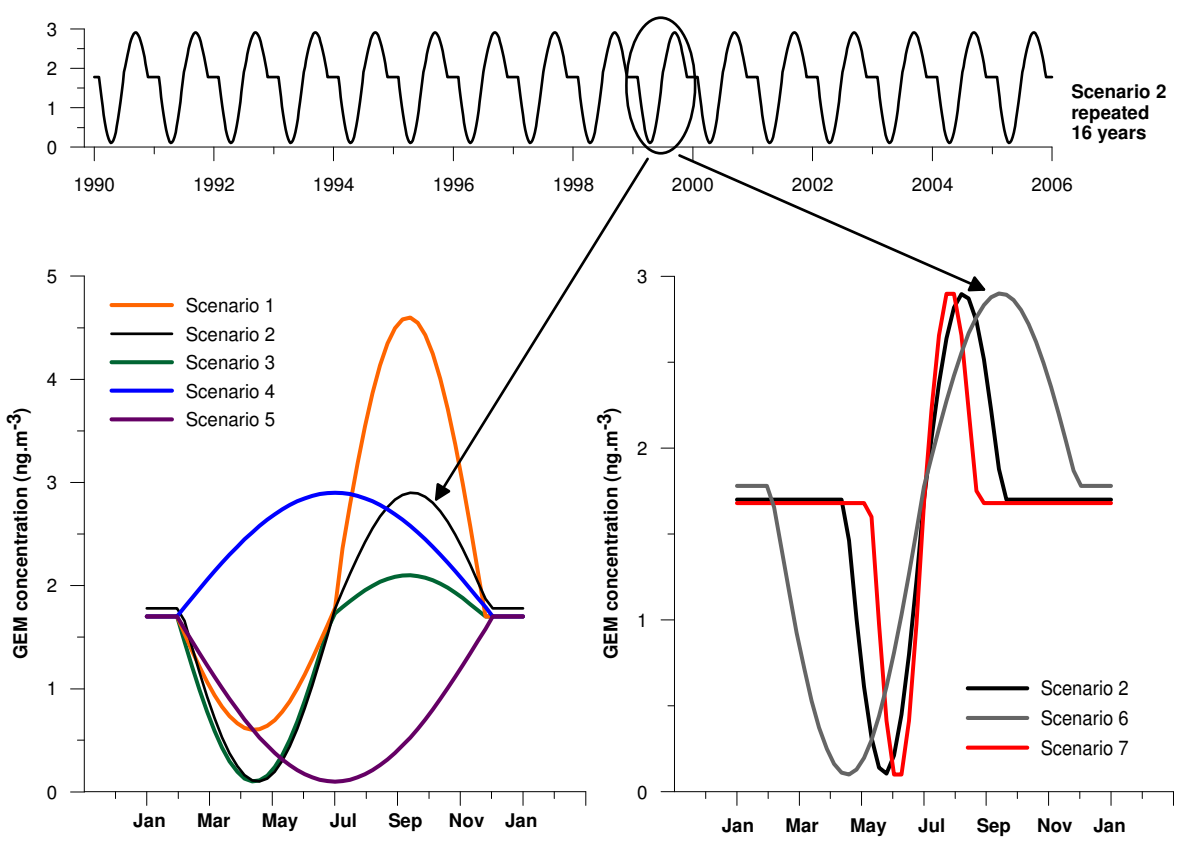

Fig. 10. Annual scenarios of the evolution of GEM concentrations at the bottom of the Chemical Zone ( $2.7 \mathrm{~m}$ depth in the snowpack). Each scenario is repeated during 16 years for diffusion in the deeper firn.

expected at the depth $z_{c}$. We begin by assuming $z_{\text {SEAS }}$ is at most $15 \mathrm{~m}$, since GEM concentrations were constant from 15 to $30 \mathrm{~m}$ depths. To be consistent with measurements carried out in the chemical zone in both summer 2005 and spring 2006, we considered GEM concentrations at depth $z_{C}$ ranging from a minimum at the beginning June $\left(0.1 \mathrm{ng} \mathrm{m}^{-3}\right)$ to a maximum at the end of July $\left(2.9 \mathrm{ng} \mathrm{m}^{-3}\right)$, and we adjust winter concentrations to the constant atmospheric background (i.e. $1.65 \mathrm{ng} \mathrm{m}^{-3}$ ). We fitted the mean annual concentration to $\sim 1.65 \mathrm{ng} \mathrm{m}^{-3}$ to match the observed value at a depth of $15 \mathrm{~m}$, and we adjusted the length of the winter (i.e. constant concentration period) so as to not observe GEM variations deeper than $15 \mathrm{~m}$. These constraints lead to cycle 7 in Fig. 10. The expression of this cycle in the firn between $z_{C}$ and $30 \mathrm{~m}$ is shown in Fig. 11. The blue line indicates the expected GEM concentration profile in June and is consistent with data collected at $3.3,15,25$ and $30 \mathrm{~m}$. As discussed in Sect. 3.4.4, production or destruction of GEM in the shallow firn can dominate, depending on season (spring vs. summer), leading to elevated or depleted GEM concentrations. The results from the model presented in Fig. 11 lead us to conclude that the annual mean concentration at a depth of $2.7 \mathrm{~m}$ in the firn air at Summit Station is close to the atmospheric level. This result is of prime importance: we can interpret the signal from a depth of $15 \mathrm{~m}$ and the close-off solely as a record of the long-term atmospheric trend. Moreover, the shape of cycle 7 (Fig. 10) indicates that GEM chemistry in the snowpack probably occurs only during the brief period between May and September, which suggests that chemical processes involving GEM in the shallow firn could be linked to solar radiation. We assumed in this study that no photochemical processes were occurring in the SIA below $60 \mathrm{~cm}$ 


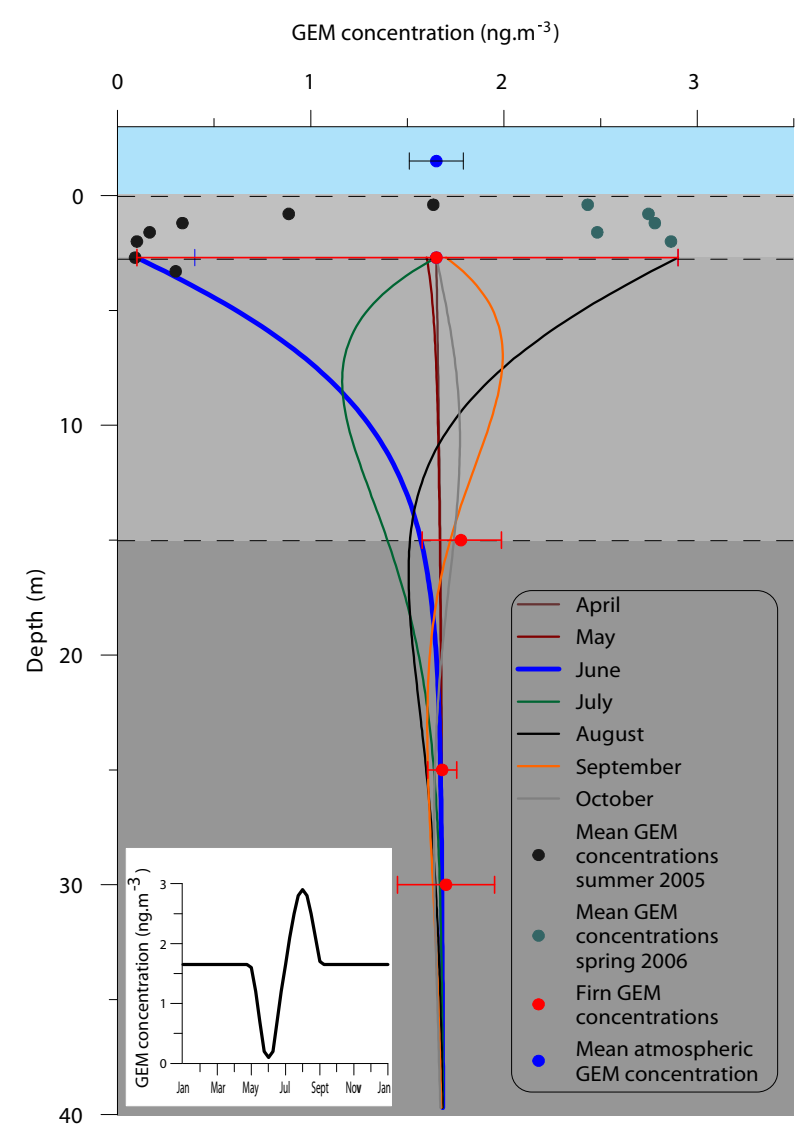

Fig. 11. Diffusion from 2.7 to $30 \mathrm{~m}$ depth of a seasonal variation of GEM happening at the bottom of the Chemical Zone. This annual pattern, represented in the white box, was repeated 16 years. We showed GEM profiles induced in the Diffusion Zone at different months. The blue line represents the profile expected in June, and agrees with firn data collected from 2.7 to $30 \mathrm{~m}$ depth.

depth, according to Galbavy et al. (2007). However we expect that future studies will investigate the transmission of solar irradiance deeper within the snowpack.

\subsection{Implications for the transfer function}

Our measurements of GEM close to the surface revealed a high variability of GEM concentrations on a daily time scale, as well as a seasonal shift in the chemical mechanisms affecting GEM levels. Daily fluctuations in GEM concentrations are too fast relative to diffusion times to influence the firn GEM record beyond a depth of $\sim 3 \mathrm{~m}$. Moreover, our modeling work showed that seasonal variations are not expressed in the deep firn. In principle, the first $70 \mathrm{~m}$ of the firn could show signs of seasonality, but our best estimates of the seasonal variations of GEM lead us to expect that only the first $15 \mathrm{~m}$ of the firn air contain detectable influences of shallowfirn chemistry. This implies that firn air from a depth of $15 \mathrm{~m}$ to the close-off has the potential to be used to reconstruct the atmospheric history of GEM over the last decades. Further- more, the conservative nature of GEM below $\sim 3 \mathrm{~m}$ indicates that it is possible to calculate the GEM transfer function at Summit Station using more detailed information on the diffusivity of the firn between $\sim 3 \mathrm{~m}$ and the close-off.

\section{Conclusions}

Atmospheric Mercury Depletion Events were not observed at Summit Station during both summer 2005 and spring 2006, and are unlikely to occur, since Ozone Depletion Events have never been reported for this site. In air extracted from the snowpack between 40 and $200 \mathrm{~cm}$ depths, GEM concentrations showed variability at daily and seasonal time scales. Both production and oxidation of GEM were observed during spring (beginning of June) and summer (end of July), but the respective contributions of each process change with time during the season. Oxidation is the dominant mechanism during spring, and production dominates during summer. We postulate that dark oxidation chemistry can influence GEM levels in the SIA. While the shallowest firn at Summit Station acts as a source and a sink of GEM for the lower atmosphere, the deeper firn air contains a record of the evolution of atmospheric GEM concentrations since it is not perturbed by surface processes. In particular, the daily variations of GEM concentrations are too rapid to influence the firn record and the influence of seasonal variations does not extend below the first $15 \mathrm{~m}$ of the firn. From a depth of $15 \mathrm{~m}$ to the close-off (about $\sim 79.5 \mathrm{~m}$ at Summit Station), the firn air should provide a record of the past atmospheric GEM composition.

Acknowledgements. This research was funded by US National Science Foundation Office of Polar Programs project NSF-OPP 0520445, the French PNCA program "Echanges Neige Polaire", the French Ministry of Research (A.C.I. JC 3012) and the Laboratoire de Glaciologie et Géophysique de l'Environnement (LGGE, Grenoble, France). We thank our Summit collaborators for their assistance during the field campaigns (especially Zoe Courville of Dartmouth/CRREL, Chandler Engel of UVM, and Meaghan Tanguay of Bowdoin College). The summer Summit crew, VECO Polar Resources and the Air National Guard provided logistical support during the field experiments. We thank the Danish Polar Board and Greenlandic Home Rule Government for permission to work in Greenland, and the technical staff of LGGE for help in preparing our field campaigns. Thanks are also due to Xavier Bigard and Nadine Simler who helped for the calibration of our instruments (CRSSA, La Tronche France), and to the Institute for Atmospheric and Climate Science (ETH, Zurich, Switzerland) for providing us meteorological data. Christophe Ferrari thanks the Institut Universitaire de France (I.U.F.) for helping to finance this study. In Italy this work was supported by the Consorzio per l'Attuazione del Programma Nazionale delle Ricerche in Antartide, under projects on Environmental Contamination and Glaciology. ELGA LabWater is acknowledged for providing the PURELAB Option-R and Ultra Analytic systems, which produced the ultra-pure water used in ICPMS experiments.

Edited by: J. Burrows 


\section{References}

Albert, M. R.: Modeling heat, mass, and species transport in polar firn, Ann. Glaciol., 23, 138-143, 1996.

Albert, M. R., Grannas, A. M., Bottenheim, J., Shepson, P. B., and Perron Jr., F. E.: Processes and properties of snow-air transfer in the high Arctic with application to interstitial ozone at Alert, Canada, Atmos. Environ., 36, 2779-2787, 2002.

Albert, M. R. and Shultz, E. F.: Snow and firn properties and airsnow transport processes at Summit, Greenland, Atmos. Environ., 36(15-16), 2789-2797, 2002.

Ariya, P. A., Dastoor, A. P., Aymot, M., Schroeder, W. H., Barrie, L. A., Anlauf, K., Raofie, F., Ryzhkov, A., Davignon, D., Lalonde, J. D., and Steffen, A.: The Artic, a sink for mercury, Tellus, 56B, 397-403, 2004.

Ariya, P. A., Khalizov, A., and Gidas, A.: Reactions of gaseous mercury with atomic and molecular halogens: kinetics, product studies, and atmospheric implications, J. Phys. Chem. A, 106(32), 7310-7320, 2002.

Aspmo, K., Gauchard, P. A., Steffen, A., Temme, C., Berg, T., Balhmann, E., Banic, C., Dommergue, A., Ebinghaus, R., Ferrari, C., Pirrone, N., Sprovieri, F., and Wibetoe, G.: Measurements of atmospheric mercury species during an international study of mercury depletion events at Ny-Alesund, Svalbard, spring 2003. How reproducible are our present methods?, Atmos. Environ., 39, 7607-7619, doi:10.1016/j.atmosenv.2005.07.065, 2005.

Assonov, S. S., Brenninkmeijer, C. A. M., Jöckel, P., Mulvaney, R., Bernard, S., and Chappellaz, J.: Evidence for a CO increase in the SH during the $20^{t h}$ century based on firn air samples from Berkner Island, Antarctica, Atmos. Chem. Phys., 7, 295-308, 2007 , http://www.atmos-chem-phys.net/7/295/2007/.

Battle, M., Bender, M. L., Sowers, T., Tans, P. P., Butler, J. H., Elkins, J. W., Ellis, J. T., Conway, T., Zhang, N., Lang, P., and Clarke, A. D.: Atmospheric gas concentrations over the past century measured in air from firn at the South Pole, Nature, 383, 231-235, 1996.

Biester, H., Bindler, R., Martinez-Cortizas, A., and Engstrom, D. R.: Modeling the past atmospheric deposition of mercury using natural archives, Environ. Sci. Technol., 41(14), 4851-4860, doi:10.1021/es0704232, 2007.

Boutron, C. F., Vandal, G. M., Fitzgerald, W. F., and Ferrari, C. P.: A forty-year record of mercury in central Greenland snow, Geophys. Res. Lett., 25(17), 3315-3318, 1998.

Brooks, S., Arimoto, R., Lindberg, S., and Southwork, G.: Antarctic polar plateau snow surface conversion of deposited oxidized mercury to gaseous elemental mercury with fractional long-term burial, Atmos. Environ., 2877-2884, doi:10.1016/j.atmosenv.2007.05.029, 2007.

Butler, J. H., Battle, M., Bender, M. L., Montzka, S. A., Clarke, A. D., Saltzmank, E. S., Sucher, C. M., Severinghaus, J. P., and Elkins, J. W.: A record of atmospheric halocarbons during the twentieth century from polar firn air, Nature, 399, 749-755, 1999.

Dibb, J. E., Albert, M., Anastasio, C., Atlas, E., Beyersdorf, A. J., Blake, N. J., Blake, D. R., Bocquet, F., Burkhart, J. F., Chen, G., Cohen, L., Conway, T. J., Courville, Z., Frey, M. M., Friel, D. K., Galbavy, E. S., Hall, S., Hastings, M. G., Helmig, D., Huey, L. G., Hutterli, M. A., Jarvis, J. C., Lefer, B. L., Meinardi, S., Neff, W., Oltmans, S. J., Rowland, F. S.,
Sjostedt, S. J., Steig, E. J., Swanson, A., and Tanner, D. J.: An overview of air-snow exchange at Summit, Greenland: recent experiments and findings, Atmos. Environ., 41(24), 4995-5006, doi:10.1016/j.atmosenv.2006.12.006, 2007.

Dominé, F., Albert, M., Huthwelker, T., Jacobi, H.-W., Kokhanovsky, A. A., Lehning, M., Picard, G., and Simpson, W. R.: Snow physics as relevant to snow photochemistry, Atmos. Chem. Phys., 8, 171-208, 2008, http://www.atmos-chem-phys.net/8/171/2008/.

Dommergue, A., Balhmann, E., Ebinghaus, R., Ferrari, C., and Boutron, C.: Laboratory simulation of $\mathrm{Hg}^{\circ}$ emissions from a snowpack, Anal. Bioanal. Chem., 288(2), 319-327, doi:10.1007/s00216-007-1186-2, 2007.

Dommergue, A., Ferrari, C. P., and Boutron, C. F.: First investigation of an original device dedicated to the determination of gaseous mercury in interstitial air in snow, Anal. Bioanal. Chem., 375, 106-111, 2003a.

Dommergue, A., Ferrari, C. P., Poissant, L., Gauchard, P.-A., and Boutron, C. F.: Diurnal cycles of gaseous mercury within the snowpack at Kuujjuarapik/Whapmagoostui, Québec, Canada, Environ. Sci. Technol., 37(15), 3289-3297, 2003b.

Ebinghaus, R., Jennings, S. G., Schroeder, W. H., Berg, T., Donaghy, T., Guentzel, J., Kenny, C., Kock, H. H., Kvietkus, K., Landing, W., Muhleck, T., Munthe, J., Prestbo, E. M., Schneeberger, D., Slemr, F., Sommar, J., Urba, A., Wallschlager, D., and Xiao, Z.: International field intercomparison measurements of atmospheric mercury species at Mace Head, Ireland, Atmos. Environ., 33(18), 3063-3073, 1999.

Ebinghaus, R. and Slemr, F.: Aircraft measurements of atmospheric mercury over southern and eastern Germany, Atmos. Environ., 34, 895-903, 2000.

Engstrom, D. R. and Swain, E. B.: Recent Declines in Atmospheric Mercury Deposition in the Upper Midwest, Environ. Sci. Technol., 31, 960-967, 1997.

Fabre, A., Barnola, J.-M., Arnaud, L., and Chappellaz, J.: Determination of gas diffusivity in polar firn: comparison between experimental measurements and inverse modeling, Geophys. Res. Lett., 27(4), 557-560, 2000.

Faïn, X., Grangeon, S., Balhmann, E., Fritsche, J., Obrist, D., Dommergue, A., Ferrari, C., Cairns, W., Ebinghaus, R., Barbante, C., Cescon, P., and Boutron, C.: Diurnal production of Gaseous Mercury in the alpine snowpack before snowmelt, J. Geophys. Res., 112, D21311, doi:10.1029/2007JD008520, 2007.

Ferrari, C. P., Dommergue, A., and Boutron, C. F.: Profiles of Mercury in the snow pack at Station Nord, Greenland shortly after polar sunrise, Geophys. Res. Lett., 31, L03401, doi:10.1029/2003GL018961, 2004a.

Ferrari, C. P., Dommergue, A., Skov, H., Goodsite, M., and Boutron, C. F.: Nighttime production of elemental gaseous mercury in interstitial air of snow at Station Nord, Greenland, Atmos. Environ., 38, 2727-2735, 2004b.

Ferrari, C. P., Moreau, A. L., and Boutron, C. F.: Clean conditions for the determination of ultra-low levels of mercury in ice and snow samples, Fresenius J. Anal. Chem., 366, 433-437, 2000.

Foster, K. L., Plastridge, R. A., Bottenheim, J., Shepson, P., Finlayson-Pitts, B. J., and Spicer, C. W.: The role of $\mathrm{Br}_{2}$ and $\mathrm{BrCl}$ in surface ozone destruction at polar sunrise, Science, 291, 471-474, doi:10.1126/science.291.5503.471, 2001.

Galbavy, E. S., Anastasio, C., Lefer, B. L., and Hall, S.: 
Light penetration in the snowpack at Summit, Greenland: part 2 nitrate photolysis, Atmos. Environ., 41(24), 5091-5100, doi:10.1016/j.atmosenv.2006.01.066, 2007.

Gardfeldt, K. and Jonsson, M.: Is bimolecular reduction of $\mathrm{Hg}$ (II) complexes possible in aqueous systems of environmental importance, J. Phys. Chem. A, 107, 4478-4482, 2003.

Goodsite, M. E., Plane, J. M. C., and Skov, H.: A Theoretical Study of the Oxidation of $\mathrm{Hg}^{\circ}$ to $\mathrm{HgBr}_{2}$ in the Troposphere, Environ. Sci. Technol., 38, 1772-1776, 2004.

Helmig, D., Bocquet, F., Cohen, L., and Oltmans, S. J.: Ozone uptake to the polar snowpack at Summit, Greenland, Atmos. Environ., 41(24), 5061-5076, doi:10.1016/j.atmosenv.2006.06.064, 2007a.

Helmig, D., Oltmans, S. J., Carlsona, D., Lamarque, J.-F., Jones, A., Labuschagne, C., Anlauf, K., and Hayden, K.: A review of surface ozone in the polar regions, Atmos. Environ., 41(24), 51385161, doi:10.1016/j.atmosenv.2006.09.053, 2007b.

Khal, J. D., Martinez, D. A., Kuhns, H., Davidson, C. I., Jaffrezo, J.-L., and Harris, J. M.: Air mass trajectories to Summit, Greenland: a 44-year climatology and some episodic events, J. Geophys. Res., 102(C12), 26 861-26875, 1997.

Lalonde, J. D., Amyot, M., Doyon, M.-R., and Auclair, J.-C.: Photo-induced $\mathrm{Hg}(\mathrm{II})$ reduction in snow from the remote and temperate Experimental Lake Area (Ontario, Canada), J. Geophys. Res., 108(D6), 4200, doi:10.1029/2001JD001534, 2003.

Lalonde, J. D., Poulain, A. J., and Amyot, M.: The Role of Mercury Redox Reactions in Snow on Snow-to-Air Mercury Transfer, Environ. Sci. Technol., 36(2), 174-178, 2002.

Lamborg, C. H., Fitzgerald, W. F., O’Donnell, J., and Torgersen, T.: A nonsteady-state compartemental model of global-scale mercury biogeochemistry with interhemispheric atmospheric gradients, Geochim. Cosmochim. Acta, 66, 1105-1118, 2002.

Lin, C.-J. and Pehkonen, S. O.: The chemistry of atmospheric mercury: a review, Atmos. Environ., 33, 2067-2079, 1999.

Lindqvist, O. and Rodhe, H.: Atmospheric mercury-a review, Tellus, 37B, 136-159, 1985.

Mann, J. L., Long, S. E., Shuman, C. A., and Kelly, W. R.: Determination of mercury content in a shallow firn core from greenland by isotope dilution inductively coupled plasma mass spectrometry, Water Air Soil Poll., 163, 29-32, 2004.

Martinerie, P., Raynaud, D., Etheridge, D. M., Barnola, J.-M., and Mazaudier, D.: Physical and climatic parameters which influence the air content in polar ice, Earth Planet. Sci. Lett., 112, 1-13, 1992.

Mason, R. P., Fitzgerald, W. F., and Morel, F. M. M.: The biogeochemical cycling of elemental mercury : anthropogenic influences, Geochim. Cosmochim. Acta, 58(15), 3191-3198, 1994.

Mason, R. P. and Sheu, G.-R.: Role of the ocean in the global mercury cycle, Global Biogeochem. Cyc., 16(4), 1093, doi:1029/2001GB001440, 2002.

Massman, W. J.: Molecular diffusivities of $\mathrm{Hg}$ vapor in air, $\mathrm{O}_{2}$ and $\mathrm{N}_{2}$ near STP and the kinematic viscosity and thermal diffusivity of air near STP, Atmos. Environ., 33, 453-457, 1999.

Montzka, S. A., Aydin, M., Battle, M., Butler, J. H., Saltzman, E. S., Hall, B. D., Clarke, A. D., Mondeel, D., and Elkins, J. W.: A 350-year atmospheric history for carbonyl sulfide inferred from Antarctic firn air and air trapped in ice, J. Geophys. Res., 109, D22302, doi:10.1029/2004JD004686, 2004.

Oum, K. W., Lakin, M. J., and Finlayson-Pitts, B. J.: Bromine acti- vation in the troposphere by the dark reaction of $\mathrm{O}_{3}$ with seawater ice, Geophys. Res. Lett., 25(21), 3929-3926, 1998.

Peterson, M. C. and Honrath, R. E.: Observations of rapid photochemical destruction of ozone in snowpack interstitial air, Geophys. Res. Lett., 28(3), 511-514, 2001.

Planchon, F. A. M., Gabrielli, P., Gauchard, P. A., Dommergue, A., Barbante, C., Cairns, W. R. L., Cozzi, G., Nagorski, S. A., Ferrari, C. P., Boutron, C. F., Capodaglio, G., Cescon, P., Varga, A., and Wolff, E. W.: Direct determination of mercury at the subpicogram per gram level in polar snow and ice by ICP-SFMS, J. Anal. Atom. Spectrom., 19, 823-830, doi:10.1039/b402711f, 2004.

Poulain, A. J., Lalonde, J. D., Amyot, M., Shead, J. A., Raofie, F., and Ariya, P. A.: Redox transformations of mercury in an Arctic snowpack at springtime, Atmos. Environ., 38, 6763-6774, 2004.

Raofie, F. and Ariya, P. A.: Product study of the gas-phase BrOinitiated oxidation of $\mathrm{Hg}-0$ : evidence for stable $\mathrm{Hg} 1+$ compounds, Environ. Sci. Technol., 38(16), 4319-4326, 2004.

Rommelaere, V., Arnaud, L., and Barnola, J.-M.: Reconstructing recent atmospheric trace gas concentrations from polar firn and bubbly ice data by inverse methods, J. Geophys. Res., 102, 30 069-30 083, 1997.

Schroeder, W. H., Anlauf, K. G., Barrie, L. A., Lu, J. Y., Steffen, A., Schneeberger, D. R., and Berg, T.: Arctic springtime depletion of mercury, Nature, 394, 331-332, 1998.

Schroeder, W. H., Keeler, G., Kock, H., Roussel, P., Schneeberger, D., and Schaedlich, F.: International field intercomparison of atmospheric mercury measurement methods, Water Air Soil Poll., 80, 611-620, 1995.

Schuster, P. F., Krabbenhoft, D. P., Naftz, D. L., Dewayne Cecil, L., Olson, M. L., Dewild, J. F., Susong, D. D., Green, J. R., and Abbott, M. L.: Atmospheric Mercury Deposition during the Last 270 Years: A Glacial Ice Core Record of Natural and Anthropogenic Sources, Environ. Sci. Technol., 36(11), 2303-2310, 2002.

Schwander, J., Barnola, J.-M., Andrie, C., Leuenberger, M., Ludin, A., Raynaud, D., and Stauffer, B.: The age of the air in the firn and the ice at Summit, Greenland, J. Geophys. Res., 98, 28312838, 1993.

Schwander, J., Stauffer, B., and Sigg, A.: Air mixing in firn and the age of the air at pore close-off, Ann. Glaciol., 10, 141-145, 1988.

Siegenthaler, U., Stocker, T., Monnin, E., Lüthi, D., Schwander, J., Stauffer, B., Raynaud, D., Barnola, J.-M., Fischer, H., MassonDelmotte, V., and Jouzel, J.: Stable carbon cycle-climate relationship during the late pleistocene, Science, 310(5752), 13131317, 2005.

Sjostedt, S. J., Huey, L. G., Tanner, D. J., Peischl, J., Chen, G., Dibb, J. E., Lefer, B., Hutterli, M. A., Beyersdor, A. J., Blake, N. J., Blake, D. R., Sueper, D., Ryerson, T., Burkhart, J., and Stohl, A.: Observations of hydroxyl and the sum of peroxy radicals at Summit, Greenland during summer 2003, Atmospheric Environment, 41(24), 5122-5137, doi:10.1016/j.atmosenv.2006.06.065, 2007.

Skov, H., Christensen, J., Goodsite, M., Heidam, N. Z., Jensen, B., Wahlin, P., and Geernaert, G.: Fate of Elemental Mercury in the Arctic during Atmospheric Mercury Depletion Episodes and the Load of Atmospheric Mercury to the Arctic, Environ. Sci. Technol., 38, 2373-2382, 2004.

Steffen, A., Schroeder, B., MacDonald, R. W., Poissant, L., and 
Konoplav, A.: Mercury in the Arctic atmosphere: An analysis of eight years of measurements of GEM at Alert (Canada) and a comparison with observations at Amderma (Russia) and Kuujjuarapik (Canada), Sci. Total Environ., 342, 185-198, doi:10.1016/j.scitotenv.2004.12.048, 2005.

Swanson, A., Blake, N. J., Blake, D. R., Rowland, F. S., Dibb, J. E., Lefer, B. L., and Atlas, E.: Are methyl halides produced on all ice surfaces? Observations from snow-laden field sites, Atmos. Environ., 41(24), 5162-5177, doi:10.1016/j.atmosenv.2006.11.064, 2007.

Tang, T. and McConnell, J. C.: Autocatalytic release of bromine from Arctic snowpack during polar sunrise, Geophys. Res. Lett., 23, 2633-2636, 1996.
Tossel, J. A.: Calculation of the Energetics for Oxidation of GasPhase Elemental $\mathrm{Hg}$ by $\mathrm{Br}$ and BrO, J. Phys. Chem. A, 107, 7804-7808, 2003.

Trudinger, C. M., Etheridge, D. M., Rayner, P. J., Enting, I. G., Sturrock, G. A., and Langenfelds, R. L.: Reconstructing atmospheric histories from measurements of air composition in firn, J. Geophys. Res., 107(D24), 4780, doi:10.1029/2002JD002545, 2002.

Warren, S. G., Brandt, R. E., and Grenfell, T. C.: Visible and nearultraviolet absorption spectrum of ice from transmission of solar radiation into snow, Appl. Opt., 45(21), 5320-5334, 2006. 